\title{
The influence of African air pollution on regional and global tropospheric ozone
}

\author{
A. M. Aghedo ${ }^{1,2}$, M. G. Schultz ${ }^{3}$, and S. Rast $^{1}$ \\ ${ }^{1}$ Max Planck Institute for Meteorology, Hamburg, Germany \\ ${ }^{2}$ International Max Planck Research School on Earth System Modelling, Hamburg, Germany \\ ${ }^{3}$ ICG-II, Research Centre, Jülich, Germany
}

Received: 3 May 2006 - Published in Atmos. Chem. Phys. Discuss.: 4 July 2006

Revised: 19 January 2007 - Accepted: 15 February 2007 - Published: 22 February 2007

\begin{abstract}
We investigate the influence of African biomass burning, biogenic, lightning and anthropogenic emissions on the tropospheric ozone over Africa and globally using a coupled global chemistry climate model. Our model studies indicate that surface ozone concentration may rise by up to $50 \mathrm{ppbv}$ in the burning region during the biomass burning seasons. Biogenic emissions yield between $5-30$ ppbv increase in the near surface ozone concentration over tropical Africa. The impact of lightning on surface ozone is negligible, while anthropogenic emissions yield a maximum of 7 ppbv increase in the annual-mean surface ozone concentration over Nigeria, South Africa and Egypt. Our results show that biogenic emissions are the most important African emission source affecting total tropospheric ozone. The influence of each of the African emissions on the global tropospheric ozone burden (TOB) of $384 \mathrm{Tg}$ yields about $9.5 \mathrm{Tg}, 19.6 \mathrm{Tg}$, 9.0 $\mathrm{Tg}$ and $4.7 \mathrm{Tg}$ for biomass burning, biogenic, lightning and anthropogenic emissions emitted in Africa respectively. The impact of each of these emission categories on African TOB of $33 \mathrm{Tg}$ is $2.5 \mathrm{Tg}, 4.1 \mathrm{Tg}, 1.75 \mathrm{Tg}$ and $0.89 \mathrm{Tg}$ respectively, which together represents about $28 \%$ of the total TOB calculated over Africa. Our model calculations also suggest that more than $70 \%$ of the tropospheric ozone produced by each of the African emissions is found outside the continent, thus exerting a noticeable influence on a large part of the tropical troposphere. Apart from the Atlantic and Indian Ocean, Latin America experiences the largest impact of African emissions, followed by Oceania, the Middle East, Southeast and south-central Asia, northern North America (i.e. the United States and Canada), Europe and north-central Asia, for all the emission categories.
\end{abstract}

Correspondence to: A. M. Aghedo

(adetutu.aghedo@gmail.com)

\section{Introduction}

Air pollution emitted in Africa comes from four sources, mainly biomass burning, natural emission from vegetation and soil, lightning $\mathrm{NO}_{\mathrm{x}}$ emissions, and other anthropogenic sources - such as emissions related to the combustion of fossil-fuel for energy, industrial, transport and domestic uses. Africa contributes a significant amount to the global emissions from the first three categories, while emissions from fossil fuel combustion are important only on the regional scale. Emissions of trace species (e.g. $\mathrm{CO}, \mathrm{NO}_{\mathrm{x}}$, volatile organic compounds (VOCs)) significantly affect tropospheric chemistry and lead to the formation of tropospheric ozone, which influences the radiative forcing (e.g. Naik et al., 2005; Dentener et al., 2005).

African biomass burning activities, generally categorised as savanna, forest and agricultural waste burning, are driven by the "slash and burn" agricultural practices that take place during the dry seasons - late November to early March in the northern hemisphere $(\mathrm{NH})$, and July to October in the southern hemispheric (SH) part of Africa (Marenco et al., 1990). African biomass burning contributes about $40 \%$ to trace species emitted by global biomass burning activities (Crutzen et al., 1979; Andreae, 1991; Helas et al., 1995, Schultz et al., $2007^{1}$ ), and exerts a large influence on tropospheric chemistry (Crutzen and Andreae, 1990; Andreae, 1993; Helas et al., 1992, 1995; Marufu et al., 2000). Marufu et al. (2000) used a global chemistry transport model to test the sensitivity of tropospheric ozone over Africa to emissions from biomass burning from all over the world and found that about $16 \%$ of the $26 \mathrm{Tg}$ tropospheric ozone burden (TOB) over Africa is due to these global biomass burning emissions.

\footnotetext{
${ }^{1}$ Schultz, M. G., Heil, A., Hoelzemann, J. H., Spessa, A., Thonicke, K., Goldammer, J., Held, A. C., and Pereira, J. M.: Global Emissions from Wildland Fires in 1960 to 2000, Global Biogeochem. Cycles, in review, 2007.
} 
Lightning produces $\mathrm{NO}_{\mathrm{x}}$, mostly in the middle to upper troposphere (Ridley et al., 1996; Pickering et al., 1996; Lamarque et al., 1996; Pickering et al., 1998; DeCaria et al., 2000), where it has a longer lifetime and greater ozone production potential than in the lower troposphere (Liu et al., 1987; Pickering et al., 1990). For example, DeCaria et al. (2005) calculated a photochemical ozone enhancement of about $10 \mathrm{ppbv} 24 \mathrm{~h}$ after a storm observed during the Stratosphere-Troposphere Experiment: Radiation, Aerosols and Ozone (STERAO-A) using a 3-D cloud-scale chemistry transport model (CTM). Lightning activity is maximum in the tropics. However, tropical thunderstorms are the least well characterized, therefore, the uncertainty of tropical lightning $\mathrm{NO}_{\mathrm{x}}$ is particularly large. Generally, the total contribution of lightning to the global $\mathrm{NO}_{\mathrm{x}}$ budget is highly uncertain. Estimates range from $2-20 \mathrm{Tg}(\mathrm{N})$ per year (Lawrence et al., 1995; Price et al., 1997; Huntrieser et al., 2002; Labrador et al., 2005). However, several studies published after 2000 have suggested an estimate closer to the lower limit. Huntrieser et al. (2002) estimated about $3 \mathrm{Tg}(\mathrm{N}) \mathrm{yr}^{-1}$ from lightning $\mathrm{NO}_{\mathrm{x}}$ based on detailed analysis of airborne $\mathrm{NO}_{\mathrm{x}}$ measurements of European thunderstorms. Tie et al. (2001) and Martin et al. (2002) found that using a global lightning emission value of $7 \mathrm{Tg}(\mathrm{N}) \mathrm{yr}^{-1}$ and $6 \mathrm{Tg}(\mathrm{N}) \mathrm{yr}^{-1}$ respectively, their model simulations show reasonable agreement with airborne observations of reactive nitrogen species.

Vegetation emits a wide range of VOCs (Kesselmeier and Staudt, 1999). Among these biogenic VOCs, isoprene is one of the most important (e.g., Fehsenfeld et al., 1992; Guenther et al., 1995), followed by terpenes and methanol $\left(\mathrm{CH}_{3} \mathrm{OH}\right)$. Estimates of global isoprene emissions vary between $200 \mathrm{Tg}$ and $600 \mathrm{Tg}$ (Kesselmeier and Staudt, 1999; Guenther et al., 2006, and references therein), of which Africa contributes about a fifth. Biogenic VOCs can have a significant impact on tropospheric chemistry as soon as they are released into the air, because of their high reactivity. They lead to the production (or destruction) of ozone in high (or low) $\mathrm{NO}_{\mathrm{x}}$ conditions. Wang and Shallcross (2000) found an increase in surface ozone concentration of about 4 ppbv over the ocean and about 8-12 ppbv over the mid-latitude land areas when isoprene emissions were included in their 3-D model simulations. Using biogenic $\mathrm{CH}_{3} \mathrm{OH}$ emissions of $117 \mathrm{Tg}(\mathrm{C}) \mathrm{yr}^{-1}$, Tie et al. (2003) calculated an increase of about $3-4 \%$ in the tropical ozone at $300 \mathrm{hPa}$.

In this study we performed multi-year sensitivity calculations with a newly developed global chemistry climate model using the biomass burning, biogenic and anthropogenic emissions employed in the recent IPCC-ACCENT simulations in preparation for the fourth assessment report (e.g. see Stevenson et al., 2006; Shindell et al., 2006). The lightning $\mathrm{NO}_{\mathrm{x}}$ emissions are calculated interactively within our model. These sensitivity studies are used to investigate the regional and global influence of each of the African emissions on primary and secondary tropospheric trace species concentrations. In particular, we focus on tropospheric ozone produced from the photochemical reactions involving precursors emitted in Africa. Tropospheric ozone is a greenhouse gas (Wang et al., 1980; Hansen et al., 2002), high ozone concentrations in the air affect human health (e.g. Peden, 2001; Desqueyroux et al., 2002; Mortimer et al., 2002) and damage vegetation, including agricultural crops (e.g. Mauzerall and Wang, 2001; Oksanen and Holopainen, 2001).

A brief description of our model and the setup of the simulation experiments are given in Sects. 2 and 3 respectively. An evaluation of ECHAM5-MOZ is presented in Sect. 4. The results of the sensitivity experiments are discussed in Sect. 5. Conclusions and a summary are given in Sect. 6.

\section{The global chemistry climate model ECHAM5-MOZ}

The full description of ECHAM5-MOZ and its sensitivity to the use of different emission inventories can be found in Rast et al. $(2007)^{2}$. The 3-D global chemistry climate model ECHAM5-MOZ is part of the Max Planck Institute, Hamburg Earth System Model (ESM) and consists of the 3-D global general circulation model (GCM) ECHAM5 (Roeckner et al., 2003) and the 3-D global CTM, MOZART2 (Horowitz et al., 2003), with modified parameterizations of dry and wet deposition, surface ultraviolet (UV) albedo, and lightning $\mathrm{NO}_{\mathrm{x}}$ production. The ECHAM5-MOZ model employs a consistent link of the chemistry calculation with the parameterisation of the dynamics and the physics of the ECHAM5 model.

\subsection{Atmospheric dynamics}

The dynamical core of ECHAM5 solves prognostic equations for vorticity, divergence, logarithm of surface pressure and temperature expressed in spectral coefficients. The vertical axis uses a hybrid terrain-following sigma-pressure coordinate system (Simmons and Burridge, 1981). The model uses a semi-implicit leapfrog time integration scheme (Robert et al., 1972; Robert, 1981, 1982) with a special time filter (Asselin, 1972). Details of the physical parameterisations including radiation, surface processes, gravity wave drag, convection, stratiform cloud formation, orbit variations, and subgrid scale orography can be found in Roeckner et al. (2003). ECHAM5 (and thus ECHAM5-MOZ) can be run in various horizontal resolutions such as $\mathrm{T} 42$ $\left(\sim 2.8^{\circ} \times 2.8^{\circ}\right)$, T63 $\left(\sim 1.9^{\circ} \times 1.9^{\circ}\right)$ and T106 $\left(\sim 1^{\circ} \times 1^{\circ}\right)$ using 19 or $31 \sigma$-hybrid vertical levels. It can also be run as a coupled ocean-atmosphere model or in an atmosphereonly mode. In this study, we have constrained sea surface

\footnotetext{
${ }^{2}$ Rast, S., Schultz, M. G., Aghedo, A. M., Diehl, T., Rhodin, A., Schmidt, H., Stier, P., Ganzeveld, L. and Walters, S.: Sensitivity of a chemistry climate model to changes in emissions and the driving meteorology, in preparation, 2007.
} 
temperatures (SST) and sea ice (SIC) by output from coupled ocean-atmosphere model simulations performed in the framework of the fourth IPCC assessment report (Roeckner et al., 2006) in an Atmospheric Model Intercomparison Project 2 (AMIP2, Gates et al., 1999) set-up. The effect of varying model resolutions on the simulated climate is described in Roeckner et al. (2006).

\subsection{Tracer transport and deposition}

Tracers in ECHAM5-MOZ undergo advective and convective transport, vertical diffusion, dry and wet deposition, and chemical reactions in the atmosphere. The advection of tracers is based on a mass conserving flux-form semi Lagrangian transport scheme (Lin and Rood, 1996) on a Gaussian grid (Arakawa C-grid, Mesinger and Arakawa (1976)). Convective transport is parameterized according to the mass-flux algorithm of Tiedtke (1989) with modifications proposed by Nordeng (1994). ECHAM5-MOZ extends the vertical diffusion equations of ECHAM5 to include the net flux of tracers at the earth's surface (e.g. emission and dry deposition). The dry deposition is formulated according to the scheme of Ganzeveld (2001). The wet deposition is based on the scheme of Stier et al. (2005), with modifications for belowcloud scavenging for $\mathrm{HNO}_{3}$ (Seinfeld and Pandis, 1998, , page 1003). This dynamical wet deposition scheme takes into consideration the solubility of the tracers and the possibility of the release of trace gases into the atmosphere by re-evaporation of precipitation. The sensitivity of transport of tracers in ECHAM5 to model resolution, forcing meteorology and their chemical lifetime is discussed in Aghedo et al. $(2007)^{3}$.

\subsection{Chemistry scheme}

The ECHAM5-MOZ model uses the MOZART2 tropospheric chemistry scheme, consisting of 63 transported species and 168 chemical reactions. The details of the chemical species, reactions, kinetic equations and the chemistry solver are described in Horowitz et al. (2003). As in the original MOZART model, the ECHAM5-MOZ chemical reaction scheme is flexible due to the MOZART2 preprocessor which produces machine dependent optimized (e.g. vectorized and parallelized) code for a specific set of user-defined reactions. An implicit Euler method is applied for the integration of the kinetic nonlinear differential equations for most of the species.

\subsection{Lightning emissions}

ECHAM5-MOZ includes interactive lightning $\mathrm{NO}_{\mathrm{x}}$ emissions according to the parameterisation of Grewe et al.

\footnotetext{
${ }^{3}$ Aghedo, A. M., Schultz, M. G., and Rast, S.: Sensitivity of tracer transport to model resolution and forcing data in the general circulation model ECHAM5, in preparation, 2007.
}

(2001). The lightning frequency is calculated as a function of the mean updraught velocity in a convective column. The mean updraught velocity is resolution dependent, because it depends on the size of the grid boxes. Therefore, the parameterisation contains one freely adjustable global factor that accounts for this grid-box dependency. The $\mathrm{NO}_{\mathrm{x}}$ emissions are proportional to the calculated flash frequency and are distributed vertically in the atmosphere using $\mathrm{C}$-shaped profiles for tropical and extratropical continental and marine clouds as described in Pickering et al. (1998). This parameterisation yields global lightning emissions of about $2.7 \mathrm{Tg}(\mathrm{N}) / \mathrm{yr}$ in ECHAM5-MOZ. Over Africa, total lightning emissions are about $0.7 \mathrm{Tg}(\mathrm{N}) / \mathrm{yr}$. A visual comparison of the spatial and seasonal distribution of our lightning flashes with that of Lightning Imaging Sensor (LIS) data (Christian et al., 1989, 1992 available at http://thunder.msfc.nasa.gov/data/ query/distributions.html) shows good agreement.

\subsection{Biogenic emissions}

In this study, we use the prescribed biogenic emissions from the recent IPCC-ACCENT Photocomp 2030 intercomparison experiment (Stevenson et al., 2006). The biogenic emissions are $756 \mathrm{Tg}(\mathrm{C}) \mathrm{yr}^{-1}, 68 \mathrm{Tg}(\mathrm{C}) \mathrm{yr}^{-1}$, and $8 \mathrm{Tg}(\mathrm{N}) \mathrm{yr}^{-1}$ for non-methane VOCs (NMVOC), $\mathrm{CO}$ and $\mathrm{NO}_{\mathrm{x}}$ respectively. Isoprene, terpenes and methanol account for about $68 \%, 17 \%$ and $11 \%$ of the biogenic NMVOC respectively. As an alternative to prescribed globally-gridded biogenic NMVOC emissions, ECHAM5-MOZ offers the option of an online calculation of biogenic NMVOC emissions according to the Model of Emissions of Gases and Aerosols from Nature (MEGAN) (Guenther et al., 2006).

\subsection{Other emissions}

The ECHAM5-MOZ model needs gridded emission data for emissions that are not calculated interactively. Emissions such as biomass burning (all open fires including savanna, forest, and agricultural burning), aircraft, ocean and anthropogenic emissions (such as fossil-fuel combustion by the domestic, transport and industrial sectors) are prescribed to the ECHAM5-MOZ model as monthly-mean globally gridded files. They are injected into the model at various model heights.

With the exception of the lightning emissions, which are calculated from the interactive lightning parameterisation in ECHAM5-MOZ as discussed in Sect. 2.4, all emissions used for this study are identical to those used in the IPCCACCENT experiment (Stevenson et al., 2006). These data sets are a combination of emission inventories of the Institute for Applied System Analysis (IIASA), the Global Emissions Inventory Activity (GEIA), the Global Fire Emissions Database (GFED) version 1 (Randerson et al., 2005) and the Emission Database for Global Atmospheric Research (EDGAR) version 3.2 (Olivier et al., 1999). 
Table 1. Global trace gas emissions by source used in this study and contribution from the African continent to the respective global total in parenthesis.

\begin{tabular}{lccc}
\hline Source & $\begin{array}{c}\mathrm{CO} \\
(\mathrm{Tg}(\mathrm{C}) / \mathrm{yr})\end{array}$ & $\begin{array}{c}\mathrm{NMVOC} \\
(\mathrm{Tg}(\mathrm{C}) / \mathrm{yr})\end{array}$ & $\begin{array}{c}\mathrm{NO}_{\mathrm{x}} \\
(\mathrm{Tg}(\mathrm{N}) / \mathrm{yr})\end{array}$ \\
\hline Industrial & $201(16 \%)$ & $66(14 \%)$ & $28.0(5 \%)$ \\
Biomass burning & $217(43 \%)$ & $19(42 \%)$ & $10.0(46 \%)$ \\
Biogenic & $69(20 \%)$ & $756(25 \%)$ & $8.0(30 \%)$ \\
Lightning & - & - & $2.7(26 \%)$ \\
Aircraft & - & - & $0.7(4 \%)$ \\
Ocean & $9(-)$ & $4(-)$ & - \\
All sources & $496(28 \%)$ & $845(24 \%)$ & $49.4(18 \%)$ \\
& & & $40.0(18 \%)$ \\
Marufu et al. (2000) & $482(23 \%)$ & $534(23 \%)$ & 4 \\
\hline
\end{tabular}

Anthropogenic $\mathrm{CO}, \mathrm{NO}_{\mathrm{x}}$ and $\mathrm{NMVOC}$ emissions such as domestic, industrial, road transport, off-road and powerplants fossil-fuel combustion and gas flaring are as calculated by the IIASA global version of the Regional Air Pollution Information and Simulation (RAINS) model (Amann et al., 1999) for the year 2000. The international shipping $\mathrm{CO}, \mathrm{NO}_{\mathrm{x}}$ and NMHC emissions are based on the EDGAR3.2 global emission inventory (Olivier et al., 1999), while aircraft $\mathrm{NO}_{\mathrm{x}}$ emissions are specified according to the IPCC special report on Aviation and the Global Atmosphere (IPCC, 1999).

The biomass burning emissions, which include savanna, forest and deforestation fires, and agricultural waste burning are from the GFED version 1 (Randerson et al., 2005) database available at http://daac.ornl.gov/. For the simulations described in this paper, we use the 1997-2002 average data. Ocean $\mathrm{CO}$ and soil $\mathrm{CO}, \mathrm{H}_{2}$ and $\mathrm{NO}_{\mathrm{x}}$ emissions are from the GEIA database (see Horowitz et al., 2003). The biogenic VOC emissions from vegetation are based on the global model of natural VOC contributed to the GEIA activity by Guenther et al. (1995).

Table 1 lists the global $\mathrm{CO}, \mathrm{NO}_{\mathrm{x}}$ and NMVOC emissions by source used in this study, and the amount contributed by African emissions are included as the percentages of the global emissions. It also contain the comparison of our emissions to those of Marufu et al. (2000). Our biogenic emissions are about twice as high as those of Marufu et al. (2000), while others are comparable.

\section{Model simulations}

The model experiments follow the general setup for the IPCC-ACCENT intercomparison study (Stevenson et al., 2006). The experiments were run for present-day climate and emissions. The climate conditions (sea surface temperatures and sea ice fields) were taken from six consecutive years of coupled ocean-atmosphere simulations performed at the Max Planck Institute for Meteorology, Hamburg. Present-day constant concentrations of $1760 \mathrm{ppbv}, 367 \mathrm{ppm}$ and $316 \mathrm{ppbv}$ were maintained for $\mathrm{CH}_{4}, \mathrm{CO}_{2}$ and $\mathrm{N}_{2} \mathrm{O}$ respectively.

ECHAM5 model climate simulations give better results at higher spatial resolutions (Roeckner et al., 2006). Specifically, T42L19 and T63L31 have a particularly good balance between computational costs and quality of the results. However, Aghedo et al. $(2007)^{3}$ show that the simulated transport of tracers in T42L31 is significantly different from that in T42L19, but comparable to that in the computationally more expensive T63L31 resolution. Each experiment in this study was therefore performed in the T42L31 resolution for 5 years (1997-2001) after a spin-up of 6 months.

We performed one reference experiment and 4 sensitivity experiments. The reference experiment includes all the emissions, while in each of the sensitivity experiments, we switch off one of the following emission categories over the African continent: biomass burning, biogenic, lightning, or anthropogenic emissions, respectively. The differences between the reference and the sensitivity experiments therefore show the impact of each of the African emissions.

We are aware that setting an emission source to zero affects the lifetime of other trace species in the troposphere. Nevertheless, this approach provides a relatively uncomplicated method in assessing the potential impact of these different emission types. Also, the method has the advantage that the combined effect of different species (e.g. $\mathrm{CO}, \mathrm{NO}_{\mathrm{x}}$ and $\mathrm{NMVOC}$ ) from the same emission category (e.g. biomass burning) on the overall tropospheric chemistry can be assessed. The methane lifetime (average of 7.1 years based on $150 \mathrm{ppbv}$ ozone-threshold tropopause) shows a small increase of about 13, 35 and 50 days in the experiment without anthropogenic, biomass burning and lightning emissions respectively, when compared to the reference experiment, while in the experiment where biogenic emissions are switched off, it decreases by only 32 days.

\section{Model Evaluation}

An extensive evaluation of the ECHAM5-MOZ model is described in Rast et al. (2007)2 ${ }^{2}$. In the ACCENT-IPCC scenario studies, ECHAM5-MOZ showed a high bias of about $20 \%$ in the global tropospheric ozone production and loss compared to the mean of all participating models (Stevenson et al., 2006). In terms of global dry deposition, it has a low bias of about $5 \%$. Methane and $\mathrm{CH}_{3} \mathrm{CCl}_{3}$ tropospheric lifetimes are at the lower end of the currently accepted estimations (Prinn et al., 1995; Ehhalt et al., 2001). The surface ozone concentration is known to have a high bias in heavily polluted areas, such as industrial centres and large city agglomerations but also in the Mediterranean basin.

In this section we evaluate the ECHAM5-MOZ model over Africa and its surroundings, by comparing model- 

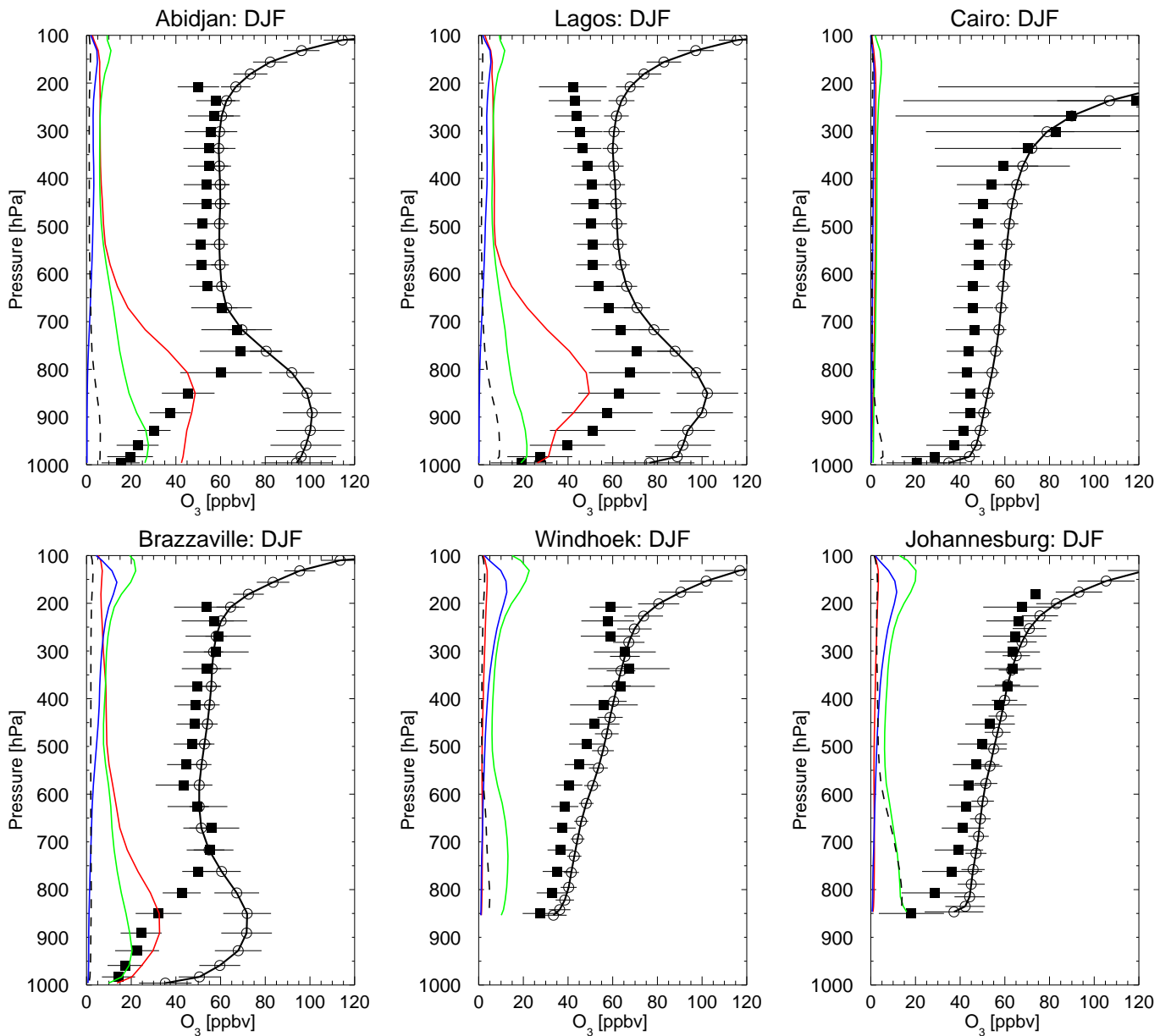

Fig. 1. The comparison of 5-year averaged model simulated (open circles with line) and 1997-2002 mean MOZAIC (filled-squares) ozone vertical profiles for Cairo (Egypt), Abidjan (Cote d'Ivoire), Lagos (Nigeria), Brazzaville (Congo), Windhoek (Namibia) and Johannesburg (South Africa) in December - February (DJF). The horizontal lines indicate $\pm 1 \sigma$ standard deviation. The figures also show the ozone enhancement due to each of the African biomass burning (red lines), biogenic (green lines), lightning (blue lines) and anthropogenic (dashedblack lines) emissions. The red, green, blue and dashed-black lines represents the difference of ozone between the reference and the sensitivitivy experiments.

calculated trace species $\left(\mathrm{O}_{3}\right.$ and $\left.\mathrm{CO}\right)$ concentrations of our reference experiment to measurements. Specifically this includes: (1) a detailed comparison of ECHAM5-MOZ vertical ozone profiles with in-situ aircraft data of the Measurement of OZone and water vapour by Airbus In-service airCraft (MOZAIC) (Marenco et al., 1998; Thouret et al., 1998a,b, 2006; Zbinden et al., 2006); (2) a comparison of ECHAM5-MOZ ozone concentration time series over Ascension Island, Irene, Reunion and Nairobi with Southern Hemisphere ADditional OZonesondes data (SHADOZ) (Thompson et al., 2003a,b), available at http://croc.gsfc.nasa. gov/shadoz/; and (3) a comparison of CO surface concentration calculated in ECHAM5-MOZ with the NOAA Earth Systems Research Laboratory Global Monitoring Division (NOAA/ESRL-GMD) CO data (Novelli et al., 1992, 1994, 1998b, 2003). Each of these comparisons is discussed below.

\subsection{ECHAM5-MOZ comparison with MOZAIC ozone data}

The aircrafts of the MOZAIC programme sample vertical profiles of ozone concentration upon departure and arrival. These profiles have been used to evaluate ECHAM5-MOZ at six African airports: Cairo (Egypt), Abidjan (Cote d'Ivoire), Lagos (Nigeria), Brazzaville (Congo), Windhoek (Namibia) and Johannesburg (South Africa). MOZAIC data provides the first ozone climatology data covering major African cities, and these data were analysed by Sauvage et al. (2005).

Figures 1 and 2 show the comparison of our reference simulation (open circles) to MOZAIC (filled squares) ozone 

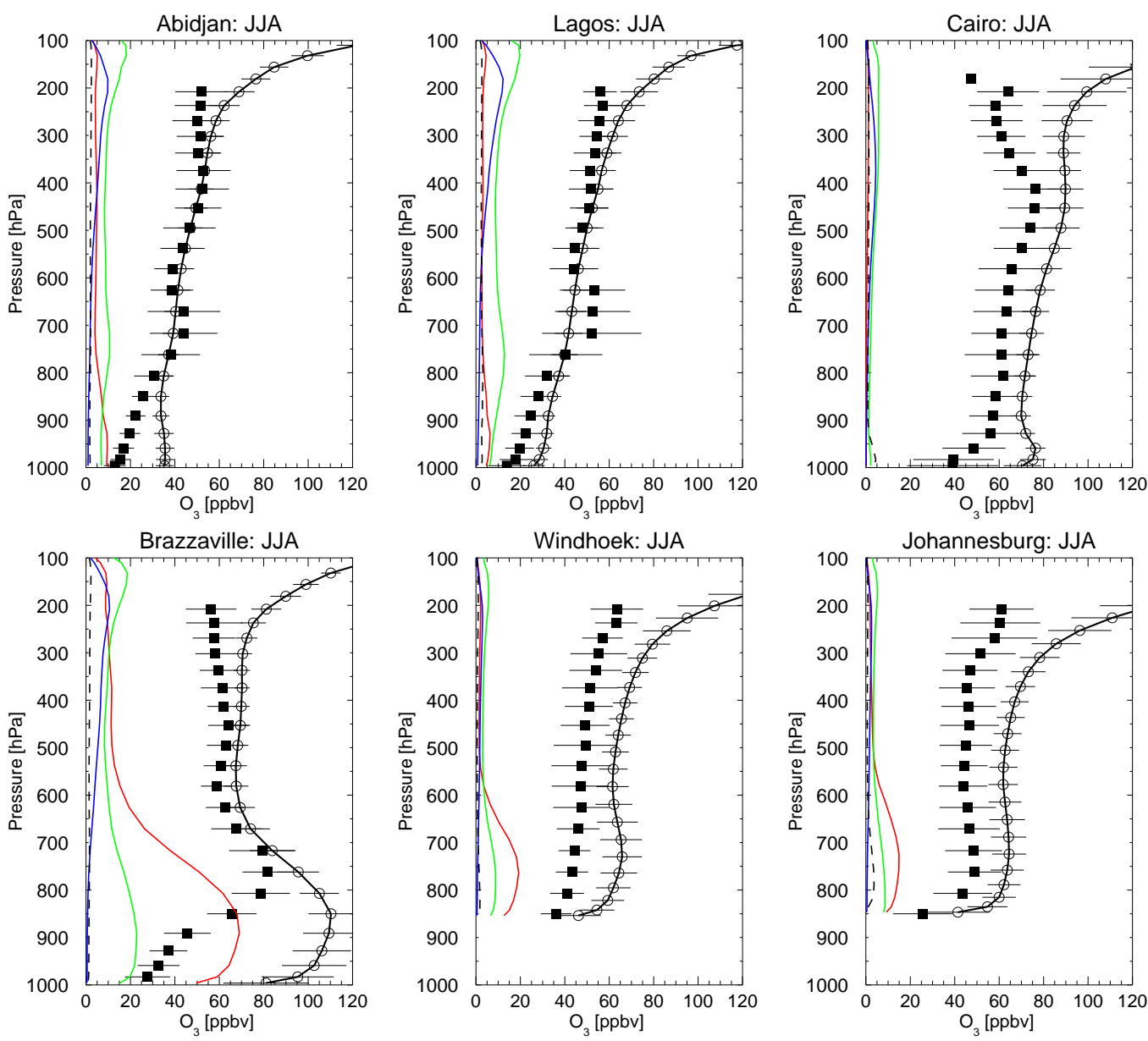

Fig. 2. Same as Fig. 1 but for June-August (JJA).

vertical profiles for these six stations in December-February (DJF), and June-August (JJA) respectively. MOZAIC data were averaged over the years 1997-2002. The ECHAM5MOZ results do not reflect specific years but can be regarded as a 5-year climatology over the late 1990s. There are no measurements at Brazzaville airport in November and December of years 1997-2002 (Sauvage et al., 2005). These figures also show the ozone enhancement due to biomass burning (red lines), biogenic (green), lightning (blue) and anthropogenic (dashed-black lines) emissions.

The ECHAM5-MOZ model shows a reasonable level of agreement with the measurements in the free troposphere $(750 \mathrm{hPa}-350 \mathrm{hPa})$ at these six stations. The model bias is about 20 ppbv, except over Cairo, Windhoek and Johannesburg in JJA, where the bias is up to 30 ppbv. During the dry season, i.e. DJF in Lagos and Abidjan, and JJA in Brazzaville, both model and measurements exhibit high ozone enhancement below- $650 \mathrm{hPa}$ over Lagos, Abidjan and Brazzaville. This is connected with an increase in local emissions of ozone precursors due to an increase in biomass burning ac- tivities in the vicinity of these stations (see Figs. 1 and 2). The reason why the ozone enhancement is limited to below$650 \mathrm{hPa}$ is due to the high stability created by a combination of the Harmattan and the Saharan anticyclone, which prevents effective vertical mixing (Sauvage et al., 2005).

However, while the dry season maximum ozone enhancement in the MOZAIC data occurs at $850-650 \mathrm{hPa}$, it is confined within the surface $-800 \mathrm{hPa}$ in the ECHAM5MOZ model. This causes ECHAM5-MOZ lower tropospheric (surface- $800 \mathrm{hPa}$ ) ozone concentrations to be highly biased during the dry season. For example, the surface ozone concentration is overestimated in ECHAM5-MOZ by about 35-50 ppbv and 50-100 ppbv over Lagos and Abidjan respectively in DJF, with the maximum bias occurring in December at both stations. Over Brazzaville, the bias in surface ozone varies between 35-60 ppbv in JJA, with a maximum overestimation in July. We identified three potential reasons for this dry season bias: (a) ECHAM5-MOZ underestimates dry deposition during the dry seasons. As already stated above, the global dry deposition in ECHAM5-MOZ 
Table 2. African emissions influence on the tropospheric ozone burden $\left(\mathrm{Tg} \mathrm{O}_{3}\right)$ of various geographical land regions. The results are the difference of the 5-year averages from the base run and the sensitivity runs where each of the emission sources were switched off one at a time.

\begin{tabular}{lccccc}
\hline Region & $\begin{array}{c}\text { Biomass } \\
\text { burning }\end{array}$ & Biogenic & Lightning & Anthropogenic & $\begin{array}{c}\text { Tropospheric } \\
\mathrm{O}_{3} \text { burden }\end{array}$ \\
\hline Africa & 2.50 & 4.07 & 1.75 & 0.89 & 33.14 \\
East Asia $^{\mathrm{a}}$ & 0.12 & 0.31 & 0.15 & 0.09 & 11.33 \\
Europe $_{\text {Latin America }}^{\mathrm{b}}$ & 0.09 & 0.24 & 0.09 & 0.09 & 14.25 \\
Middle East $^{\mathrm{c}}$ & 0.43 & 1.00 & 0.48 & 0.20 & 23.95 \\
North-central Asia $^{\mathrm{d}}$ & 0.20 & 0.53 & 0.24 & 0.18 & 11.89 \\
Oceania $^{\mathrm{e}}$ & 0.08 & 0.20 & 0.08 & 0.08 & 14.52 \\
South-central Asia $^{\mathrm{f}}$ & 0.26 & 0.57 & 0.30 & 0.14 & 9.99 \\
Southeast Asia & 0.14 & 0.33 & 0.18 & 0.08 & 7.25 \\
United States and Canada $_{\text {Global }}$ & 0.18 & 0.43 & 0.25 & 0.08 & 9.78 \\
\hline
\end{tabular}

a China, Hong Kong, Japan, Democratic peoples Republic of Korea, Republic of Korea, Macau and Taiwan.

b South America, Mexico and the Caribbean Islands.

c Middle East countries include the western part of Afghanistan, Bahrain, Cyprus, Gaza strip, Iran, Iraq, Israel, Jordan, Kazakhstan, Kuwait, Kyrgyzstan, Lebanon, Oman, Pakistan, Qatar, Saudi Arabia, Syrian Arab republic, Turkey, Turkmenistan, United Arab Emirates, Uzbekistan, West Bank and Yemen.

d Russia Federation and Mongolia.

e Australia, New Zealand, Fijis, French Polynesia, Guam, New Caledonia, Niue, Samoa and Vanuatu.

${ }^{\mathrm{f}}$ South-central Asia consist of India, Pakistan, Bangladesh, Sri-Lanka, Nepal, Maldives, Kashmir, Bhutan and the eastern Afghanistan.

$\mathrm{g}$ Southeast Asia consist of Brunei, Cambodia, East timor, Laos, Vietnam, French Indo-China, Indonesia, Malaysia, Myanmar, Papua New Guinea, Philippines, Singapore, Thailand.

is about 5\% lower than the multi-model-average dry deposition (Stevenson et al., 2006). (b) The lack of aerosols (especially mineral dust) in ECHAM5-MOZ may also contribute to this bias. (c) The particular choice of the reaction constants and their temperature dependence in ECHAM5-MOZ is known to favour high ozone concentrations in the troposphere (G. A. Folberth, personal communication, 2006). We have to point out that to fully unravel the extent of these reasons would be beyond the scope of this paper. The dry season bias in the lower troposphere will weakly influence the results presented in this study since we are interested in differences of concentrations between two simulations, however it will influence the absolute values of total tropospheric ozone burden calculated over the world regions in our reference experiment (see column 6 of Table 2).

The red lines in Fig. 1 show that the biomass-burning precursors emitted over western Africa lead to an ozone enhancement over central Africa in DJF, as shown by the ozone profile over Brazzaville. Figure 2 also shows the reverse influence of central-African biomass burning on west-African ozone in JJA, but at a lesser amount (Abidjan and Lagos). This feature has previously been found by backward trajectories calculated in Sauvage et al. (2005).

Figures 1 and 2 show that African emissions have insignificant influence over Cairo. In November-April, lower tro- pospheric ozone concentrations over Johannesburg are most sensitive to biogenic and anthropogenic emissions. At all stations except Cairo, we see a significant influence of biogenic and lightning emissions on upper tropospheric ozone concentration, especially during the wet seasons.

\subsection{ECHAM5-MOZ comparison with SHADOZ ozonesonde data}

We compare the monthly-mean time series of ozone oncentration calculated in ECHAM5-MOZ with SHADOZ data. Figure 3 shows this comparison over Ascension Island, Irene, Reunion and Nairobi at $300 \mathrm{hPa}, 500 \mathrm{hPa}$ and $800 \mathrm{hPa}$. Ozonesonde data have been collected at these four stations since 1998 till present (i.e. 2006). The SHADOZ data represent a 1998-2004 monthly average, and for the model, the ozone concentrations are the 5-year monthly average of the reference simulations.

The agreement with the SHADOZ measurements is generally good at all stations and vertical levels. The simulated values show a smaller variability (i.e. standard deviation) over the 5-year period than the measurements which represent mean values over 7 years. The seasonal cycle is well captured at most stations and vertical levels, both in amplitude and phase. Nevertheless, there are some deviations of 

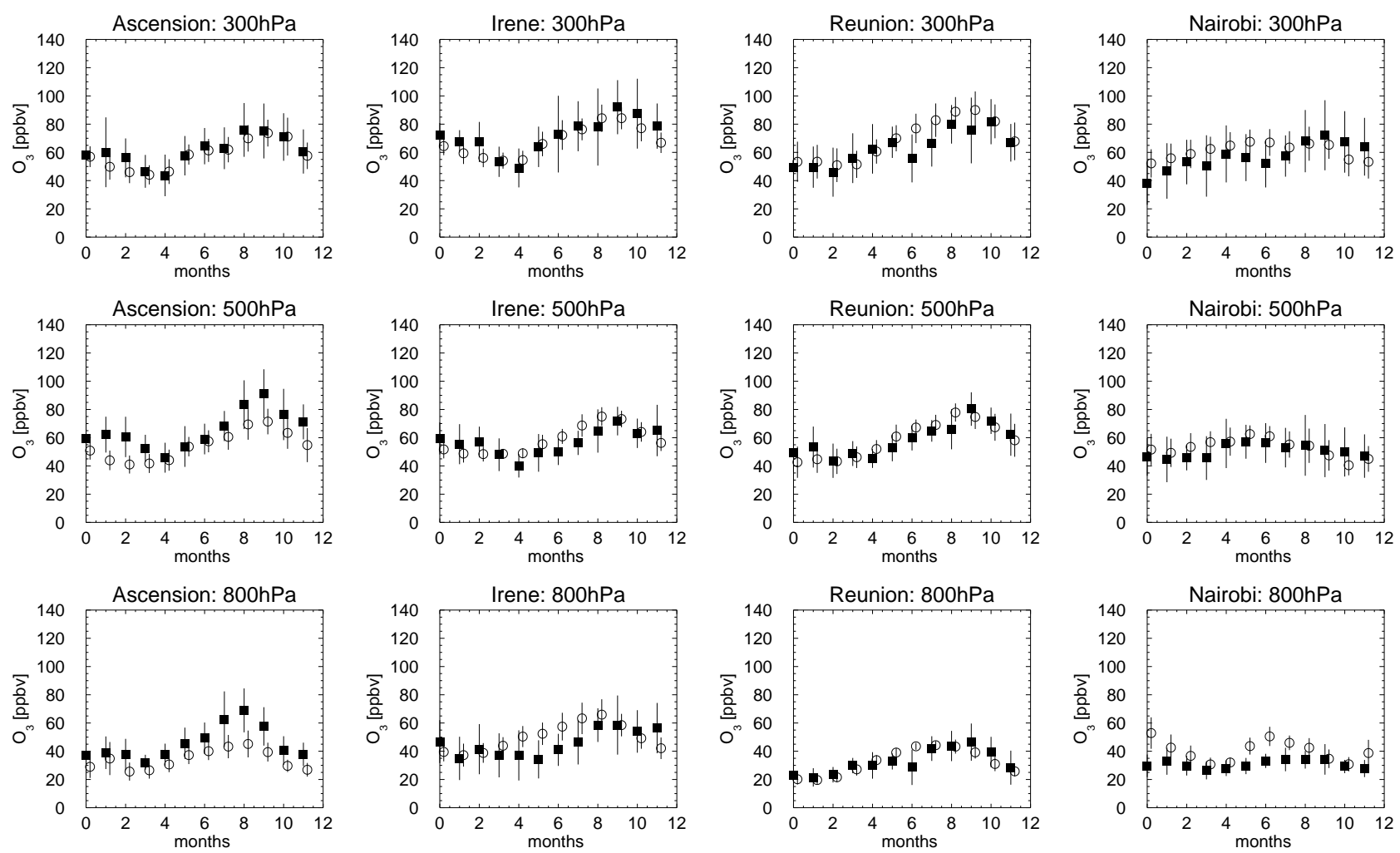

Fig. 3. The comparison of 5-year mean ECHAM5-MOZ model (open-circles) and 1998-2004 mean SHADOZ data (filled-squares) of ozone concentration (in ppbv) over Ascension, Irene, Reunion and Nairobi at $300 \mathrm{hPa}$ (top), $500 \mathrm{hPa}$ (middle), and $800 \mathrm{hPa}$ (bottom).

the model from the measurements in the lower troposphere. At $800 \mathrm{hPa}$ (Fig. 3, bottom panel), the model shows an overestimation of the ozone concentration of about $15 \mathrm{ppbv}$ at Reunion in June and July. At Irene and Nairobi, this overestimation reaches $20 \mathrm{ppbv}$ in some months. On the other hand, the model underestimates the ozone concentration over Ascension throughout the year.

In Fig. 4, we show the seasonal (JFM, AMJ, JAS, OND) bias of the ECHAM5-MOZ model when compared with SHADOZ data at Ascension Island, Irene, Reunion and Nairobi. The bias is generally lower than $20 \mathrm{ppbv}$, except at Irene in AMJ and JAS and Nairobi in JAS. Interestingly, these months represent the dry seasons at Irene and Nairobi, thereby confirming that the ECHAM5-MOZ model has a bias higher than $20 \mathrm{ppbv}$ during the dry season, which may be linked to the reasons stated earlier.

\subsection{ECHAM5-MOZ comparison with NOAA/ESRL-GMD surface $\mathrm{CO}$ concentrations data}

NOAA/ESRL-GMD has collected CO data since the 1990s (Novelli et al., 1992, 1994, 1998b, 2003). These data have been used to provide a better understanding of the $\mathrm{CO}$ global distribution (Novelli et al., 1992, 1998b), the CO budget and trends (Novelli et al., 1994, 1998a, 2003; Granier et al., 1996,
1999; Holloway et al., 2000), and were also used to validate measurements of CO made from space (Novelli et al., 1998a; Reichle et al., 1999).

We compare $\mathrm{CO}$ surface concentrations calculated in ECHAM5-MOZ with 9 stations from the NOAA/ESRLGMD CO data. These stations include 1 continental African station (Assekrem), 1 maritime African station (Mahe Island) and 7 stations downwind of Africa (see Fig. 5 for the station names and coordinates).

Figure 5 shows that the model captured the seasonal variation of surface $\mathrm{CO}$ concentration at most of the stations, and in particular in the southern hemisphere (i.e. Ascension Island, Mahe Island, Crozet Island and Syowa). At the stations north of the equator (i.e. Ragged Point, Terceira Island, Tenerife, Assekrem and Sede Boker), ECHAM5-MOZ underestimates the surface $\mathrm{CO}$ concentration, especially in January-May.

The inter-annual variability of the simulated surface $\mathrm{CO}$ concentration (error bars in Fig. 5) is generally lower than that of the measurements. This may be related to inter-annual variations in emissions, which are not included in the model since the same monthly-mean emissions are prescribed in each of the simulation years. 

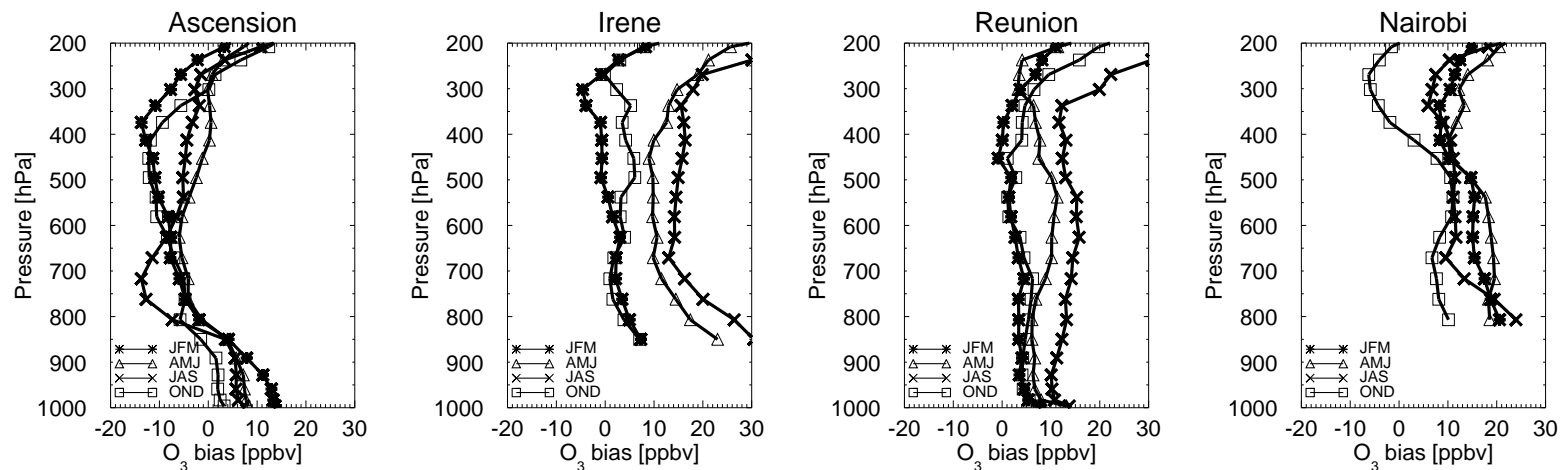

Fig. 4. The vertical profile of the seasonal mean model bias (i.e. the difference of ECHAM5-MOZ and SHADOZ) over Ascension Island, Irene, Reunion and Nairobi.
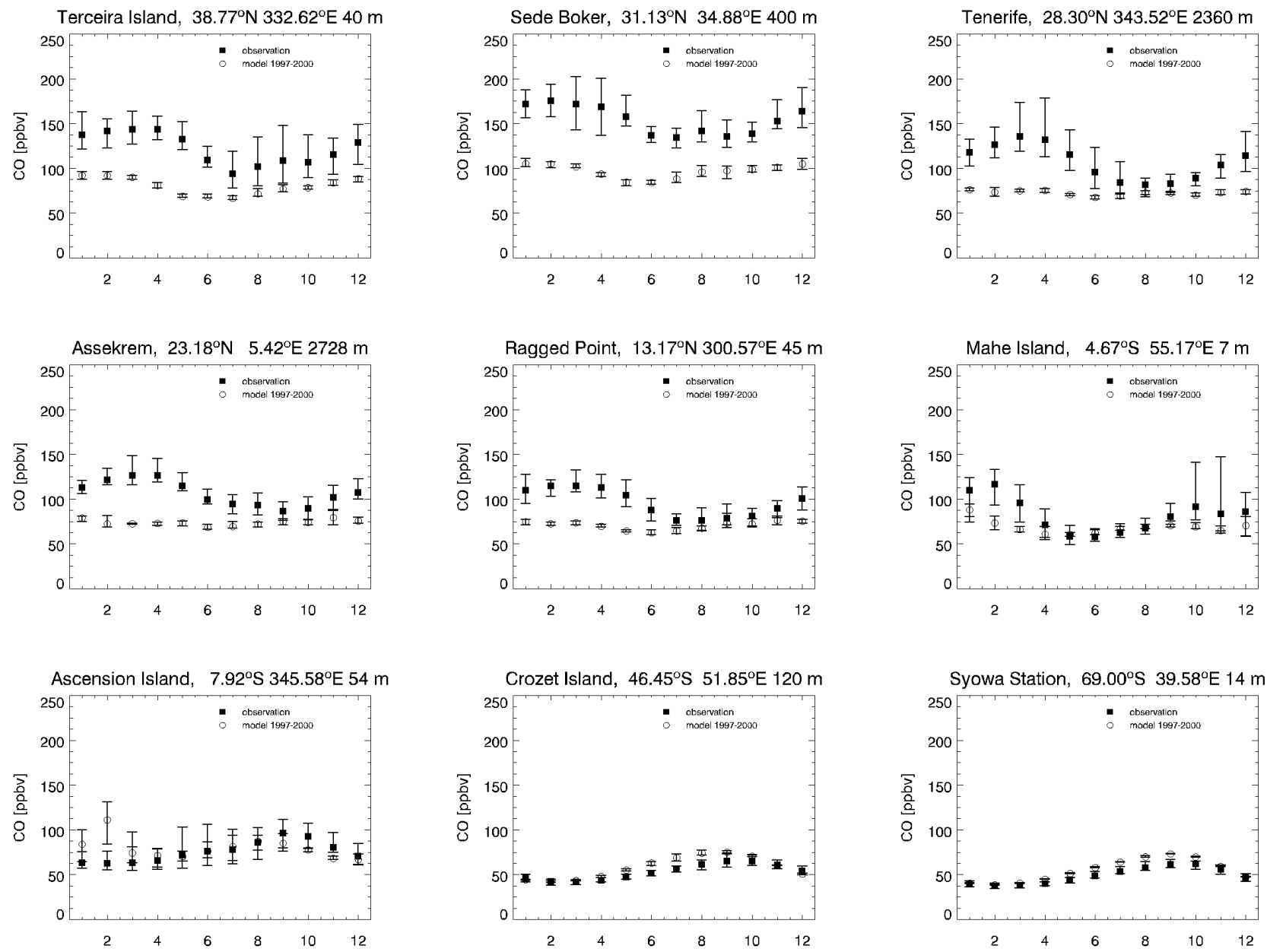

Fig. 5. Monthly mean surface CO concentrations in ECHAM5-MOZ (open circles) compared to NOAA/ESRL-GMD CO (filled squares) at Terceira Island (Azores), Sede Boker (Negev desert, Israel), Tenerife (Canary Island), Assekrem (Algeria), Ragged Point (Barbados), Mahe Island (Seychelles), Ascension Island, Crozet Islands and Syowa (Antarctica). Error bars denote the inter-annual variations in both model and measurements. 

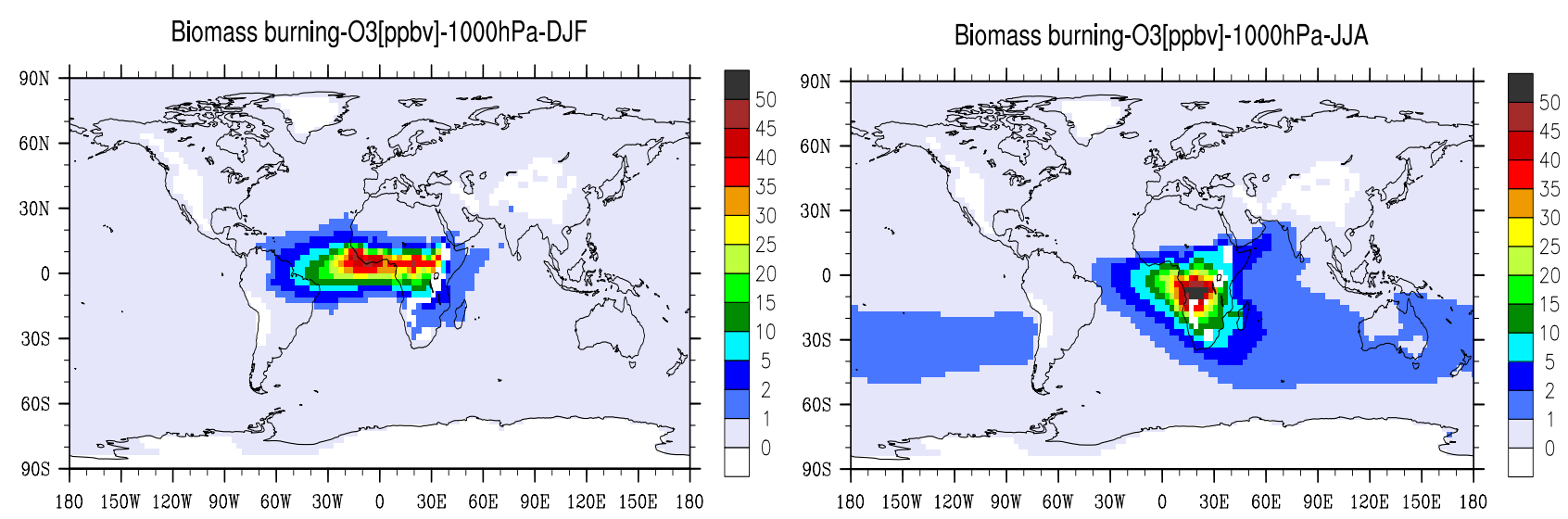

Fig. 6. The influence of African biomass burning on 5-year DJF and JJA average of the surface ozone concentrations. The figures show the difference between the reference experiment and the experiment where biomass burning emissions are excluded.
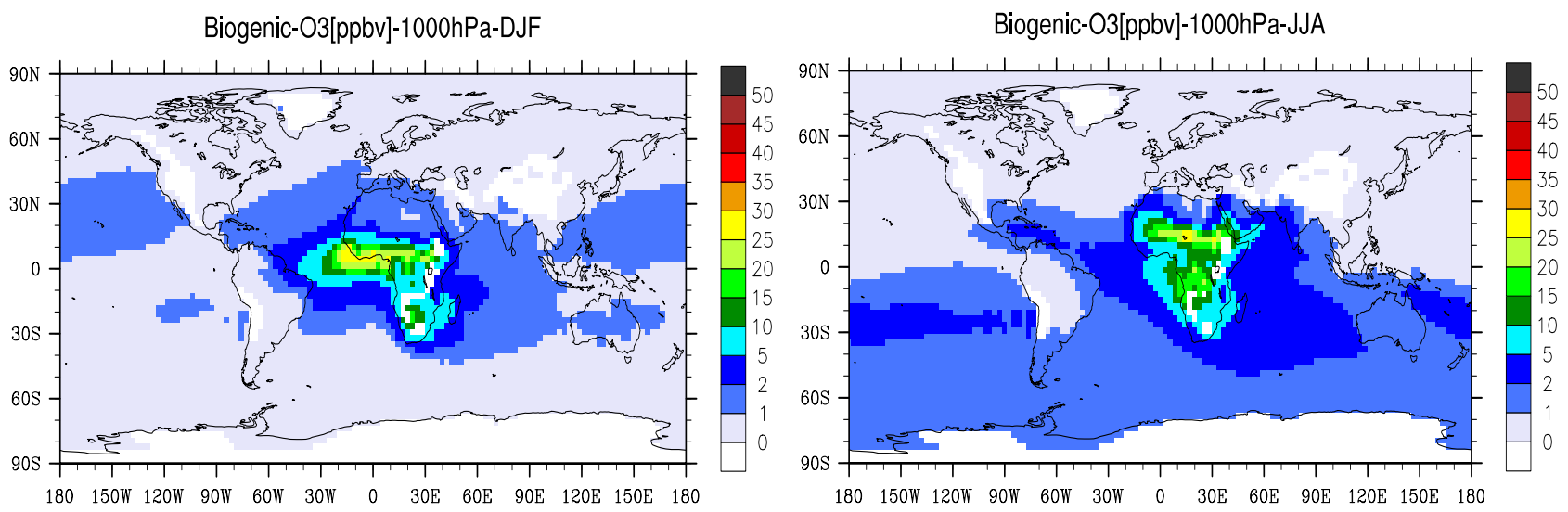

Fig. 7. The influence of African biogenic emissions on 5-year DJF and JJA average of the surface ozone concentrations. The figures show the difference between the reference experiment and the experiment where biogenic emissions are excluded.

\section{The influence of African emissions}

In Sects. 5.1 and 5.2, we discuss the impact of African emissions on the photochemical ozone production over Africa and globally. The analysis focuses on the impact of emissions on surface ozone concentrations and tropospheric ozone burden (TOB). The seasonality and inter-annual variability of the ozone burden is described in Sects. 5.3 and 5.4 respectively. We present some estimates of the uncertainty in our results in Sect. 5.5.

\subsection{The effect of African emissions on surface ozone}

The effect of African biomass burning, biogenic and anthropogenic emissions on surface ozone is shown in Figs. 6, 7 and 8 respectively. The figures show the difference in the simulated surface ozone concentrations between the reference experiment and the experiment where each of the emission types were excluded. Lightning has a small impact on surface ozone concentration, and only accounts for a maximum of $1 \mathrm{ppbv}$ over a small area in Africa, and is therefore not presented.

The enhancement of the surface ozone concentrations during the biomass burning seasons (DJF and JJA) generally lies between $10-50$ ppbv at the burning region (Fig. 6), but can reach $60 \mathrm{ppbv}$ in JJA over large parts of Democratic Republic of Congo and Angola. In DJF, there is a significant enhancement of the surface ozone concentrations over the equatorial Atlantic, reaching farther to the northeastern part of Brazil. About 1-2 ppbv surface ozone increase due to African biomass burning emissions in JJA as well as September to November (SON), can be found over the southern Atlantic, Indian and Pacific oceans.

The influence of biogenic emissions on surface ozone concentration over Africa is lower than that of biomass burning 

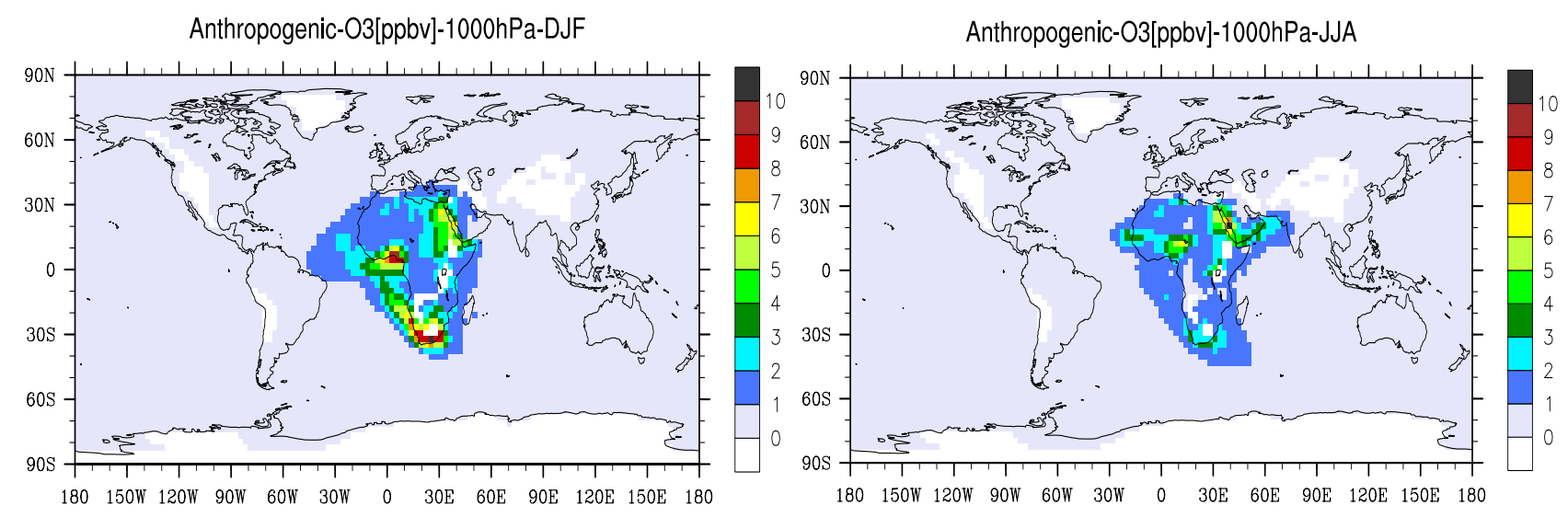

Fig. 8. The influence of African anthropogenic emissions on 5-year DJF and JJA average of surface ozone concentrations. The figures show the difference between the reference experiment and the experiment where anthropogenic emissions are excluded. Note that the scale is reduced from those of Figs. 6 and 7.

emissions in DJF and JJA (Fig. 7) in the burning regions. The highest enhancement during these 2 seasons is about 30 ppbv. However, while biomass burning surface ozone enhancement is confined to SH Africa in JJA, the influence of biogenic emissions covers both hemispheres. African biogenic emissions enhance the SH ocean surface ozone concentration by about $1-2$ ppbv in all season.

The surface ozone produced by African anthropogenic emissions (Fig. 8) shows that Nigeria, South-Africa and Egypt are the countries mainly affected by anthropogenic emissions (up to $10 \mathrm{ppbv}$ ). These three countries together account for about $35 \%, 53 \%$ and $37 \%$ of the total African anthropogenic $\mathrm{CO}, \mathrm{NO}_{\mathrm{x}}$ and $\mathrm{NMHC}$ emissions respectively. This effect therefore corresponds to the relatively high contribution of these countries to the anthropogenic emissions.

The relative importance of each of the African emission categories to surface ozone concentration over Africa thus depends on the season and the location. For example, biomass burning emissions have the largest influence in the burning regions during the dry season. Whereas, over most of the Saharan desert (i.e. north of Sahel), the surface ozone concentration is enhanced mainly by anthropogenic and biogenic emissions.

5.2 The influence of African emissions on the tropospheric ozone burden

We calculate the burden $m_{s}$ of a species $s$ in any threedimensional subdomain $\mathbb{D}$ of the atmosphere describing a particular region, e.g. troposphere over Africa, as:

$m_{s}=\sum_{j} \frac{\Delta P(j) A(j)}{g} \gamma_{s}(j) \chi_{\mathbb{D}}(j)$

where
$\Delta P(j): \quad$ absolute values of the difference between the pressure at the upper and lower boundary of the grid box $j$

$A(j)$ : area of grid box $j$

$g:$ earth acceleration

$\gamma_{s}(j)$ : mass mixing ratio of species $s$ in grid box $j$

$\chi_{\mathbb{D}}(j)$ : characteristics function of subdomain $\mathbb{D}$. It is 1 if the grid box $j$ lies in $\mathbb{D}$, otherwise it is 0 .

For the purpose of this study, the tropopause is defined as the pressure level at which the ozone concentrations are greater than or equal to $150 \mathrm{ppbv}$. The TOB discussed in this section and in subsequent sections are calculated using Eq. (1).

The TOB calculated from the reference experiment for various world regions are shown in the last column of Table 2. Our estimate of $33 \mathrm{Tg} \mathrm{TOB}$ over Africa is higher than the $26 \mathrm{Tg}$ reported by Marufu et al. (2000) using the Tracer Model version 3 (TM3), mostly due to the dry season overestimation of lower tropospheric ozone concentration in ECHAM5-MOZ.

The net influence of each of the African emissions on the regional and global TOB is shown in columns 2 through 5 of Table 2. African biomass burning, biogenic, lightning and anthropogenic emissions account for about $9.5 \mathrm{Tg}$, $19.6 \mathrm{Tg}, 8.0 \mathrm{Tg}$ and $4.7 \mathrm{Tg}$ of the global TOB respectively. Over Africa itself, the net influence of each of these emission types is only $2.5 \mathrm{Tg}, 4.1 \mathrm{Tg}, 1.75 \mathrm{Tg}$ and $0.9 \mathrm{Tg}$ respectively. This indicates that more than $70 \%$ of the tropospheric ozone produced by photochemical reactions involving African emissions is found outside the continent due to the transport of precursor species and ozone itself. The largest ozone enhancement is confined to the south Atlantic and Indian oceans. Our calculated value of $9.5 \mathrm{Tg}$ of ozone due to African biomass burning emissions is in good agreement with the $10 \mathrm{Tg}$ suggested in a marked tracer experiment described in Marufu et al. (2000). 

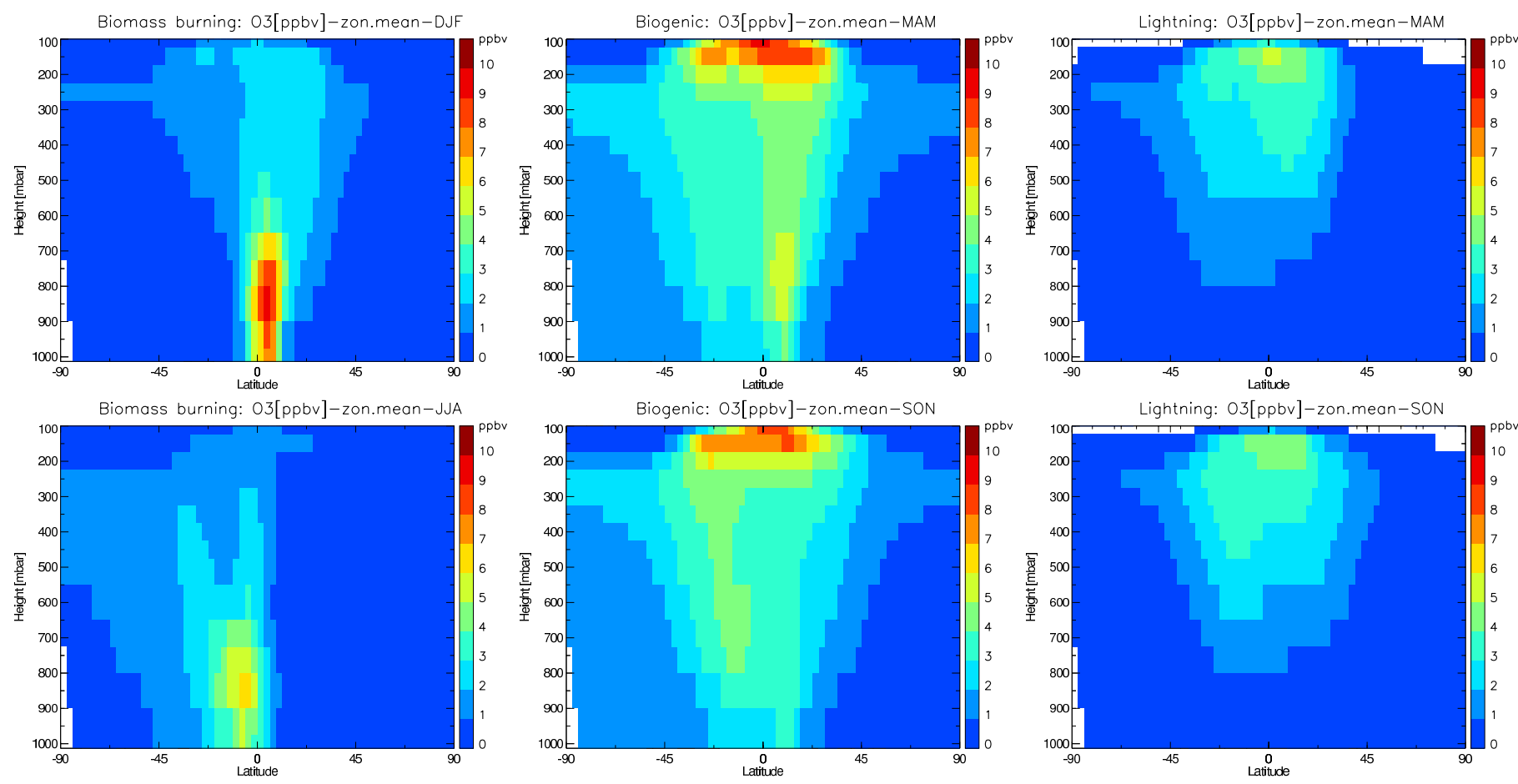

Fig. 9. 5-year zonal average of the ozone concentration (ppbv) produced by African biomass burning (left column), biogenic (middle column) and lightning (right column) emissions. The seasons with highest ozone enhancement are shown. These are DJF and JJA for Biomass burning; and MAM and SON for biogenic and lightning emissions.

Figure 9 shows the vertical profiles of the zonal average ozone concentrations produced by African biomass burning, biogenic and lightning emissions as the difference between our reference run and the respective sensitivity simulation. The two seasons shown for each emission source are those with the maximum impact of each of the emission types. These are DJF and JJA for biomass burning, and MAM and SON for biogenic and lightning emissions. The plots show 5 -year averages. The impact of African lightning emission on ozone production is highest at the middle to the upper troposphere (as shown in the right column of Fig. 9).

A striking feature in Fig. 9 (middle column) is that although biogenic emissions are released into the troposphere at the top of the vegetation canopy (as in the case of biogenic NMVOC) and at the surface (as in the case of soil emissions), relatively large ozone increases are seen in the upper troposphere (between $300 \mathrm{hPa}$ and $100 \mathrm{hPa}$ ). This may be due to the combined effect of strong convective activity in the main source region of the emissions (Collins et al., 1999; Lawrence et al., 2003; von Kuhlmann et al., 2004), the transport of biogenic NMVOC with relatively long chemical lifetime, such as methanol (Tie et al., 2003), and the effective storage of $\mathrm{NO}_{\mathrm{x}}$ as peroxy acetyl nitrate (PAN) (Fig. 10). Upon sinking of air masses containing these compounds, PAN is thermally decomposed and it releases $\mathrm{NO}_{\mathrm{x}}$ and peroxy radicals, which contribute to ozone formation. Figure 10 also shows a relatively higher $\mathrm{CO}$ concentration enhancement in the middle to upper troposphere from biogenic emissions than biomass burning emissions.

In order to estimate the direct effect of African biogenic $\mathrm{CH}_{3} \mathrm{OH}$, isoprene and terpene emissions on these concentration enhancements, we performed 3 additional sensitivity experiments for 1 year after a spin-up period of 6 months. In each of these experiments, we exclude only one of these emissions, respectively. Together, these emissions account for $96 \%$ of the biogenic NMVOC used for this study. The results show that a maximum of $65 \%$ and $15 \%$ of the upper troposphere (UT) ozone enhancement are due to African isoprene and biogenic $\mathrm{CH}_{3} \mathrm{OH}$ emissions, whereas the influence of terpenes is negligible. Therefore, the combined effect of the convective transport of biogenic methanol and isoprene, and their reaction products increases the UT ozone (Tie et al., 2003; Doherty et al., 2005).

Globally and over the continental regions outside Africa, the influence of African biogenic emissions on the tropospheric ozone burden is about two times that of biomass burning (as shown in Table 2), making them the most important African emissions category. This is due to the biogenic emissions enhancement of the ozone concentration in the middle to the upper troposphere (Fig. 9), where ozone and ozone precursors are easily transported over large distances. The largest influence of each of the African emission 

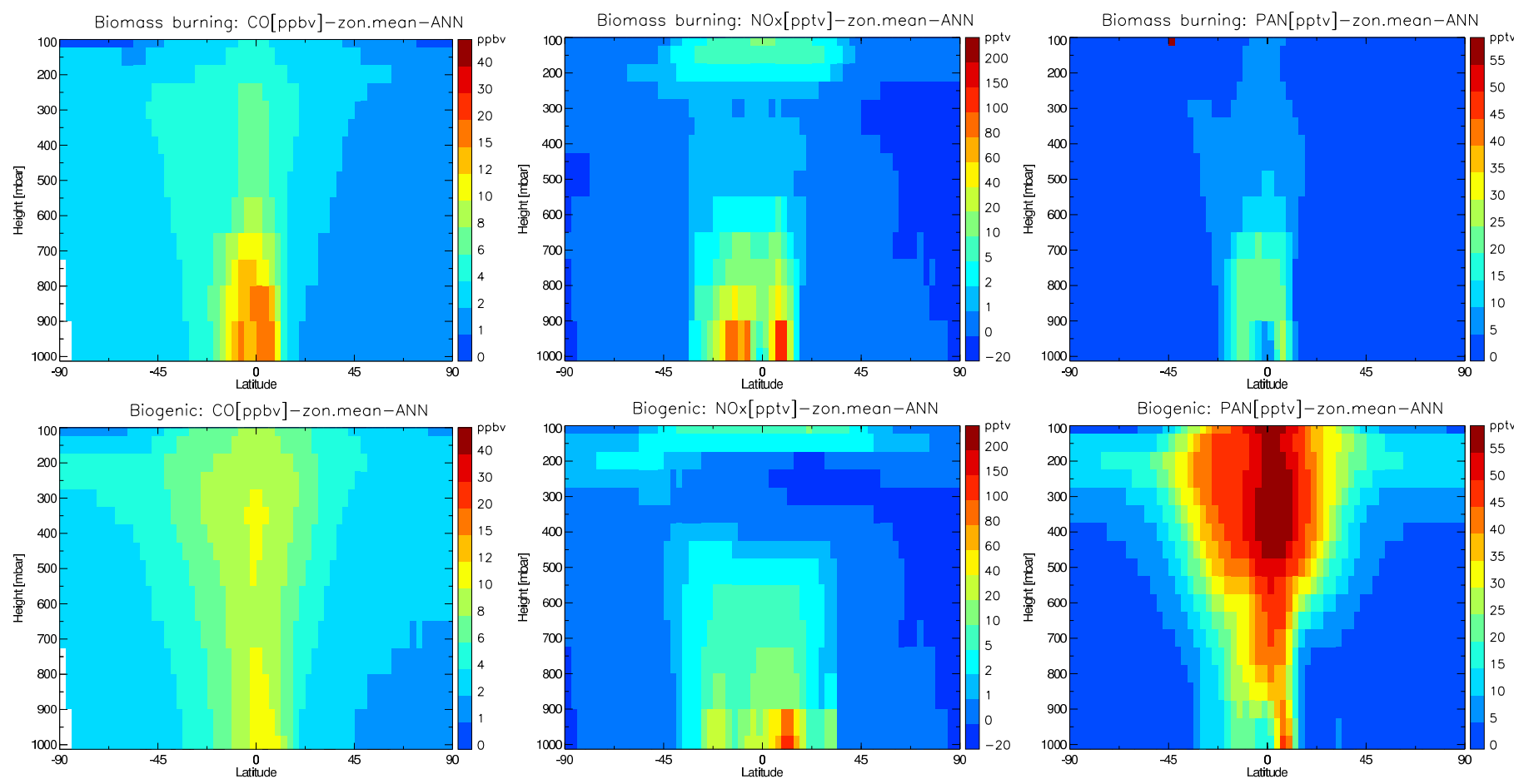

Fig. 10. 5-year zonal average of the $\mathrm{CO}, \mathrm{NO}_{\mathrm{x}}$ and peroxy acetyl nitrate (PAN) concentration produced by African biomass burning (top row) and biogenic (bottom row) emissions.
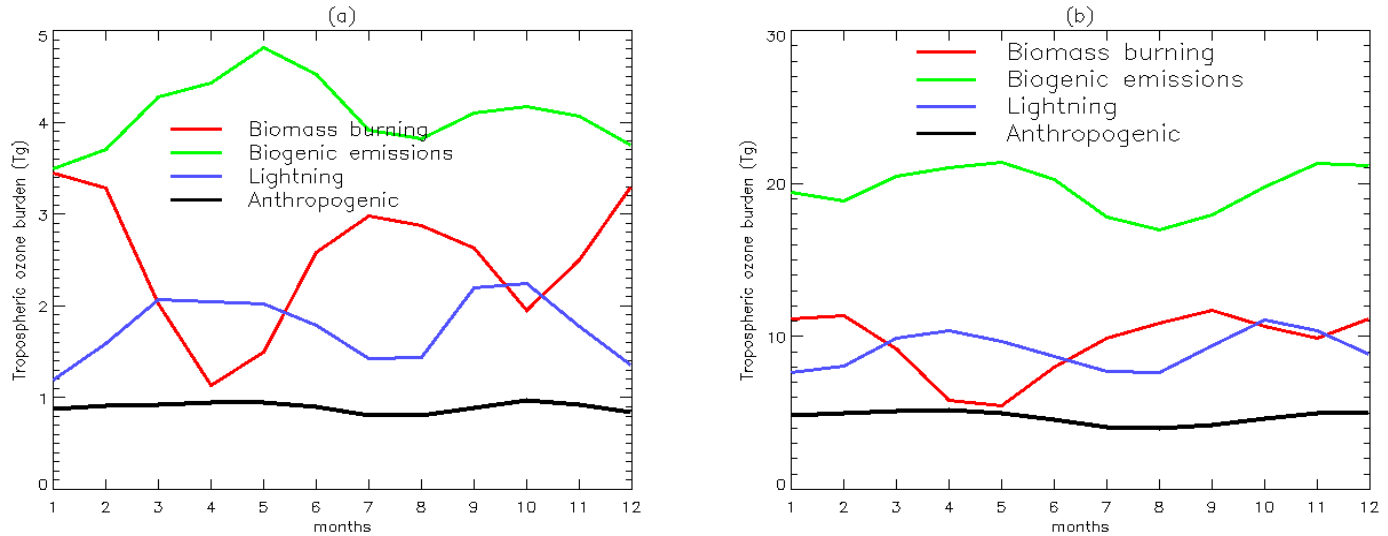

Fig. 11. The influence of African emissions on (a) African and (b) global tropospheric ozone burden ( $\left.\mathrm{Tg} \mathrm{O}_{3}\right)$. Figure shows 5-year average. Note the difference in the scales.

categories on TOB of other continental regions occurs in Latin America, followed by Oceania, the Middle East, Southeast and South-central Asia, the United States and Canada, Europe and North-central Asia (Table 2).
5.3 Seasonality of the influence of African emissions on the regional and global tropospheric ozone burden

In Fig. 11a, we show the seasonal variation of the impact of African emissions on the TOB over Africa. The seasonal variation of the tropospheric ozone burden produced by African biomass burning emissions (red line) shows two peaks. The first peak occurs between December and February, while the second peak occurs in July, with a spread from 

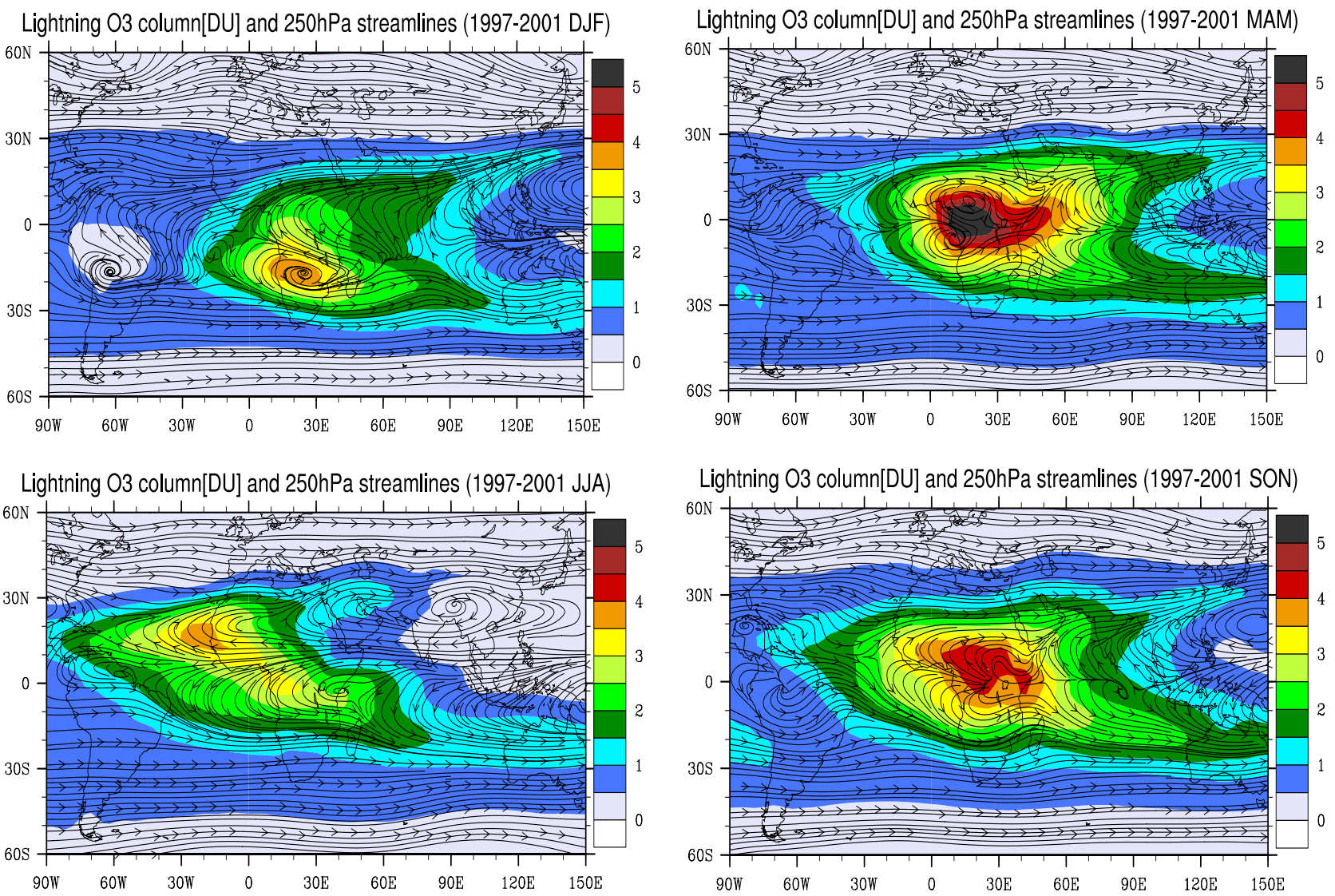

Fig. 12. The 5-year average tropospheric ozone column (DU) produced by Africa lightning $\mathrm{NO}_{\mathrm{x}}$ emissions in DJF, MAM, JJA and SON; overlaid with streamlines at $250 \mathrm{hPa}$ during the same seasons. The streamlines is generated by the $u$ and $v$ wind vectors of the reference simulations. The tropospheric ozone column is the difference of the ozone column between the reference simulation and the simulation without African lightning emissions.

June to September. This seasonality shows a high correlation with biomass burning emissions $(\mathrm{r}=0.85,0.88$ and 0.93 for biomass burning $\mathrm{NMHC}, \mathrm{CO}$ and $\mathrm{NO}_{\mathrm{x}}$ respectively), reflecting the DJF and JJA burning seasons in the NH and $\mathrm{SH}$ parts of Africa, respectively. During these peaks, the influence of African biomass burning emissions on African TOB is about $3.4 \mathrm{Tg}$ in January and 3.0 Tg in July. The seasonal variation in African TOB due to African biogenic emissions also shows a peak in May (green line in Fig. 11a) reaching 4.8 Tg. Lightning emissions over Africa yield the maximum influence on the tropospheric ozone production over the continent in two major seasons: March through May, and September through October; accounting for about $2.1 \mathrm{Tg}$ respectively (blue line in Fig. 11a).

As shown in Fig. 11, African and global TOB is most sensitive to biogenic emissions in all seasons. The two months of maximum influence of biogenic emissions on global TOB are May and November, when they account for a net TOB of $21 \mathrm{Tg}$. The highest isoprene emissions over Africa occur in April and October, while those of biogenic $\mathrm{CH}_{3} \mathrm{OH}$ occur in May and October. The seasonal variation of the global TOB produced by African biomass burning (red line in Fig. 11b) shows two peaks in December through February and in September. The maximum values are about $11.5 \mathrm{Tg}$ and $12 \mathrm{Tg}$, in February and September respectively. African lightning emissions yield their maximum influence on global TOB in April and October. During these months, their impact can be up to $10 \mathrm{Tg}$ and $11 \mathrm{Tg}$, respectively. As shown by the black lines in Fig. 11, the TOB produced by African anthropogenic emissions show a small seasonal variation.

The seasonality of the influence of African emissions on each of the world regions shown in Table 2 reveal that the maximum influence of biomass burning emissions occurs in December-March except over Oceania, where the maximum influence occurs in September-October. It turns out that burning in both hemispheres of Africa influences Latin America TOB. The maximum influence of biogenic, lightning and anthropogenic emissions on TOB over Oceania, the Middle East, Southeast and South Central Asia, and East Asia occurs generally in March-June and September- 
Table 3. Inter-annual variability of the tropospheric ozone burden produced by each of the African emission categories. The entries show the mean absolute bias in percent for various geographical land regions.

\begin{tabular}{lcccc}
\hline Region & Biomass burning & Biogenic & Lightning & Anthropogenic \\
\hline Africa & 2.4 & 2.3 & 4.9 & 2.1 \\
East Asia & 6.9 & 3.4 & 6.4 & 3.7 \\
Europe & 5.6 & 3.0 & 5.5 & 6.4 \\
Latin America & 4.2 & 3.9 & 6.8 & 3.5 \\
Middle East & 6.6 & 4.8 & 4.9 & 0.4 \\
North-central Asia & 7.5 & 3.9 & 5.5 & 4.9 \\
Oceania & 3.9 & 2.9 & 6.4 & 1.9 \\
South-Central Asia & 6.1 & 2.8 & 4.5 & 1.3 \\
Southeast Asia & 16.2 & 12.5 & 18.8 & 11.2 \\
United States and Canada & 7.2 & 3.5 & 5.6 & 4.3 \\
Global & 3.0 & 2.0 & 5.9 & 2.0 \\
\hline
\end{tabular}

December, except over Latin America, where it occured in June-September. These seasonalities reveal the combination of seasonal variation in emissions and a seasonal shift in transport pathways out of the emission source regions. This is demonstrated in the example of Fig. 12, where the spatial distribution of the total tropospheric ozone column increase due to African lightning emissions corresponds to the tranport pathways at $250 \mathrm{hPa}$ in all seasons, as shown by the streamlines. The altitude of $250 \mathrm{hPa}$ for the streamlines was chosen, because this is near the region of maximum $\mathrm{NO}_{\mathrm{x}}$ outflow in thunderstorms.

\subsection{Inter-annual variability}

Previous studies on the effect of African emissions on tropospheric ozone have always focused on one specific meteorological year. The authors are not aware of any study conducted over several years. Here we investigate the impact of changes in meteorology by analysing the inter-annual variability in our 5-years simulations. All emissions were held constant over the 5-years, but lightning emissions vary according to changes in convective activity.

We give the inter-annual variability calculated as the average deviation relative to the mean results in Table 3. Generally, the highest inter-annual variability (more than 11\%) is calculated over southeast Asia, while the smallest interannual variability (less than 5\%) is recorded over Africa for all the emission categories, for all other region, the interannual variability of the transport from Africa is less than $10 \%$. Globally, the variability is about $3.0 \%, 2.0 \%, 5.9 \%$ and $2.0 \%$ for global tropospheric ozone burden generated by African biomass burning, biogenic, lightning and anthropogenic emissions respectively.

African emissions influence tropospheric ozone over Southeast Asia throughout the year, with maximum impact in March-April and October-December. This influence is dominated by biogenic and lightning emissions, which to- gether account for about $77 \%$ of the TOB related to African emissions over Southeast Asia. The high interannual variability recorded over southeast Asia is driven by the particularly low and high transport from Africa to Southeast Asia in the third year and the fifth year of our simulation period, which causes the TOB over Southeast Asia to be about 18$34 \%$ lower and $25-40 \%$ higher than the 5-year mean TOB, respectively. This decrease and increase in transport is connected with the cold and warm anomaly in the sea surface temperature in these years, respectively (see Fig. 13). This warm (or cold) anomaly has been shown to induce a weakening (or strengthening) of the tropical easterly jet (Palmer et al., 1992; Janicot et al., 2001). The analysis of the streamline anomaly (figures not shown) at 100 to $500 \mathrm{hPa}$ reveals that the transport from Africa to Southeast Asia is enhanced (or reduced) when a warm (or cold) SST anomaly occurs.

\subsection{Uncertainties}

Simulations of the global tropospheric ozone budget are still rather uncertain; nevertheless, most models show rather good consistency in simulating the response to emission changes (Stevenson et al., 2006). There are large uncertainties in emission estimates, and these uncertainties will influence our results both in terms of absolute values and with respect to the relative importance of emission source types. While we cannot give a thorough discussion of the uncertainties here, we will at least discuss the potential impact of emission uncertainties on our ozone budget calculations assuming a linear response for simplicity.

African biomass burning emissions are uncertain by about a factor of 2 (Schultz et al., 2006) $)^{1}$. Some of this uncertainty may be related to inter-annual variability of these emissions (e.g. see, Barbosa et al., 1999), but since we do not take this variability into account in our model simulations, we can regard it as the uncertainty of the mean value here. Thus the influence of African biomass burning emissions on the global 

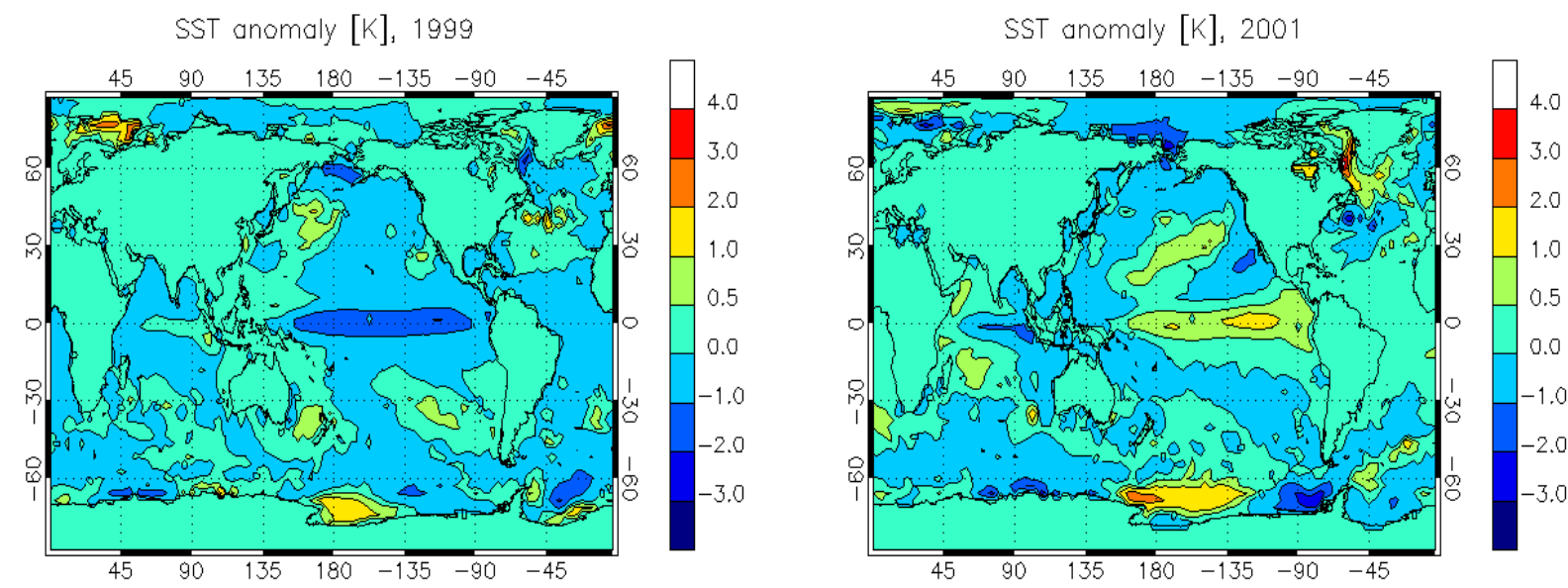

Fig. 13. The sea surface temperature (SST) anomaly in the third and the fifth year of the simulation period, with respect to the 5-year average SST.

tropospheric ozone burden could range from $4.5 \mathrm{Tg}\left(\mathrm{O}_{3}\right)$ to $19 \mathrm{Tg}\left(\mathrm{O}_{3}\right)$.

The uncertainty of global isoprene emissions reported by Guenther et al. (2006) is about a factor of 3, and about the same uncertainty factor is noted for global methanol emissions in Tie et al. (2003). However, the uncertainty of the biogenic emissions e.g. isoprene, for a specific location and time in Africa could be up to a factor of 5 (Guenther et al., 1999). Hence the influence of African biogenic emissions on global tropospheric ozone burden could range from $6.5 \mathrm{Tg}\left(\mathrm{O}_{3}\right)$ to $59 \mathrm{Tg}\left(\mathrm{O}_{3}\right)$.

The uncertainty of global lightning emissions has been briefly discussed in Sect. 1. While there is a growing consensus that the upper limit estimate of $20 \mathrm{Tg}(\mathrm{N}) \mathrm{yr}^{-1}$ is likely too high (Lawrence et al., 1995; Labrador et al., 2005), there still remains at least an uncertainty of a factor of 3. Our estimate of $2.7 \mathrm{Tg}(\mathrm{N}) \mathrm{yr}^{-1}$ is closer to the lower limit. We therefore estimate the global tropospheric ozone burden related to African lightning $\mathrm{NO}_{\mathrm{x}}$ source as $6 \mathrm{Tg}\left(\mathrm{O}_{3}\right)-30 \mathrm{Tg}\left(\mathrm{O}_{3}\right)$ for global lightning $\mathrm{NO}_{\mathrm{x}}$ emissions ranging from $2 \mathrm{Tg}(\mathrm{N}) \mathrm{yr}^{-1}$ $10 \mathrm{Tg}(\mathrm{N}) \mathrm{yr}^{-1}$.

Anthropogenic emissions are also uncertain by at least $30 \%$, but regional uncertainties may be much larger, in particular for domestic burning. We estimate that the impact of African anthropogenic emissions on the global TOB may be between 3 and $6 \mathrm{Tg}\left(\mathrm{O}_{3}\right) \mathrm{yr}^{-1}$. All together, the influence of African emissions on the global TOB may range from 20 and $114 \mathrm{Tg}(\mathrm{N}) / \mathrm{yr}$ (representing 5-30\% of the global TOB).

\section{Summary and conclusions}

We have discussed the effect of African emissions, namely: biomass burning, biogenic, lightning and anthropogenic emissions on the tropospheric ozone over Africa and in other regions of the world, using the new 3-D global atmospheric chemistry model, ECHAM5-MOZ. We gave an overall description of the model and presented a model evaluation for the region around Africa by comparing the ozone and $\mathrm{CO}$ concentration calculated by ECHAM5-MOZ to measurements at various stations. Generally ECHAM5-MOZ captures the vertical and seasonal variation of the tropospheric ozone over Africa, except that it has some high biases and overestimates the dry seasons lower tropospheric ozone concentration by more than $30 \mathrm{ppbv}$. In all other months and at all locations, the ECHAM5-MOZ ozone bias is less than $30 \mathrm{ppbv}$ everywhere in the troposphere up to $300 \mathrm{hPa}$. Interestingly, the ECHAM5-MOZ model confirms that biomass burning emissions occuring in West Africa in DJF cause lower tropospheric ozone enhancement in central Africa, with a reverse effect on western Africa during the central African burning season in JJA (Sauvage et al., 2005). ECHAM5-MOZ is also able to simulate the seasonal variation and magnitude of the surface $\mathrm{CO}$ concentration at all the stations discussed.

We have shown that African biomass burning emissions are responsible for regional surface ozone enhancement of about $10-50 \mathrm{ppbv}$ close to the burning regions. This surface ozone enhancement can even be more than $50 \mathrm{ppbv}$ over parts of central Africa (Democratic republic of Congo, Congo and Angola) during the JJA biomass burning season. Biogenic emissions increase the surface ozone concentration over Africa by about 5-30 ppbv. Lightning is shown to have an insignificant impact on surface ozone, but leads to the second largest impact on the middle to the upper tropospheric ozone concentration, next to biogenic emissions. The relative importance of biomass burning and biogenic emissions on the surface ozone concentration over Africa is highly dependent on the season and the location. Biomass burning provides the largest impact on surface ozone concentration only during the burning seasons in the vicinity of the burning 
region. The Sahara desert surface ozone concentration is mainly influenced by anthropogenic and biogenic emissions.

Biogenic, biomass burning, lightning and anthropogenic emissions over Africa account for an increase of the net global tropospheric ozone burden of about $19.6 \mathrm{Tg}(6.5-$ $60 \mathrm{Tg}), 9.5 \mathrm{Tg}(4.5-19 \mathrm{Tg}), 8.0 \mathrm{Tg}(6-30 \mathrm{Tg})$, and $4.7 \mathrm{Tg}(3-$ $6 \mathrm{Tg}$ ) respectively. The influence of these emissions on the African tropospheric ozone burden is about $4.1 \mathrm{Tg}, 2.5 \mathrm{Tg}$, $1.8 \mathrm{Tg}$ and $0.9 \mathrm{Tg}$, respectively. Therefore, this study shows that more than $70 \%$ of the tropospheric ozone produced by each of the African emission categories is found outside the continent.

We have also estimated the impact of biogenic, biomass burning, lightning and anthropogenic emissions on the tropospheric ozone burden of various world regions. We found that for all emission categories, Latin America experiences the highest impact of African emissions, followed by Oceania, the Middle East, Southeast and South-central Asia. This is in effect due to the proximity of these regions to Africa. The tropospheric ozone over Canada, the United States, Northern Asia and Europe are only slightly affected by African emissions. This study shows a teleconnection of the sea surface temperature anomaly over the eastern tropical Pacific and the transport from Africa over the central Indian Ocean to Southeast Asia. Specifically, that warm (or cold) SST anomaly increases (or reduces) transport to Southeastern Asia due to the weakening (or strengthening) of the tropical easterly jet (Palmer et al., 1992; Janicot et al., 2001). In all continental regions outside of Africa, African biogenic emissions have the largest influence on the tropospheric ozone burden, followed by African lightning and biomass burning emissions.

This study presents a discussion of the main African emission categories and their influence on regional and global tropospheric ozone. An earlier study by Marufu et al. (2000) focused on the determination of the source of tropospheric ozone over Africa, with a priority given to biomass burning emissions. Interestingly, our estimate of $9.52 \mathrm{Tg}$ due to African biomass burning emissions is comparable to the $10 \mathrm{Tg}$ estimated by Marufu et al. (2000).

Acknowledgements. This work has been sponsored by the ZEIT foundation. S. Rast and M. Schultz acknowledge partial funding from the RETRO project (EVK2-CT-00170). We acknowledge the MOZAIC data, made possible by the support of the European Commission, Airbus, CNRS-France, FZJ-Germany and the airlines (Lufthansa, Air France, Austrian and former Sabena, who carry the MOZAIC instrumentation free of charge since the commencement of the campaign in 1994). We are grateful to M. Esch, U. Schulzweida and Hui Wan for their technical assistance. We also appreciate the comments of J. Feichter, M. A. Pfeffer and H. Wan. We are grateful for the valuable comments of M. Lawrence and the anonymous referee, which have substantially improve this manuscript. The model runs were performed on the NEC SX-6 computer at the German Climate Computing Centre ("Deutsches Klimarechenzentrum" (DKRZ)).
Edited by: P. Monks

\section{References}

Amann, M., Bertok, I., Cofala, J., Gyarfas, F., Heyes, C., Klimont, Z., Makowski, M., Schöpp, W., and Syri, S.: Cost-effective Control of Acidification and Ground-Level Ozone, Seventh Interim Report, International Institute for Applied Systems Analysis (IIASA), Laxenburg, Austria, 1999.

Andreae, M. O.: Biomass burning: Its history, use, and distribution and its impact on environmental quality and global climate, in: Global Biomass Burning, edited by: Levine, J. S., MIT Press, Cambridge, Massachusetts, pp. 121, 1991.

Andreae, M. O.: The influence of tropical biomass burning on climate and the atmospheric environment, in: Biogeochemistry of Global Change: Radiatively Active Trace Gases, edited by: R. S. Oremland, Chapman and Hall, New York, 113-150, 1993.

Asselin, R.: Frequency filter for time integrations, Mon. Wea. Rev., 100, 487-490, 1972.

Aviation and the Global Atmosphere: A Special Report of IPCC Working Groups I and III in collaboration with the Scientific Assessment Panel to the Montreal Protocol on Substances that Deplete the Ozone Layer, edited by: Penner, J. E., Lister, D. H., Griggs, D. J., Dokken, D. J., and McFarland, M., Cambridge University Press, UK, pp. 373, 1999.

Barbosa, P. M., Stroppiana, D., Grégoire, J.-M., and Pereira, J. M. C.: An assessment of vegetation fire in Africa (1981-1991): Burned area, burned biomass, and atmospheric emissions, Global Biogeochem. Cycles, 13, 933-950, 1999.

Collins, W. J., Stevenson, D. S., Johnson, C. E., and Derwent, R. G.: Role of convection in determining the budget of odd hydrogen in the upper troposphere, J. Geophys. Res., 104(D21), 26927 26942, doi:10.1029/1999JD900143, 1999.

Christian, H. J., Blakeslee, R. J., and Goodman, S. J.: The Detection of Lightning from Geostationary Orbit, J. Geophys. Res., 94, 13 329-13 337, 1989.

Christian, H. J., Blakeslee, R. J., and Goodman, S. J.: Lightning Imaging Sensor (LIS) for the Earth Observing System, NASA Technical Memorandum 4350, MSFC, Huntsville, AL, February, 1992.

Crutzen, P. J., Heidt, L. E., Krasnec, W. H., and Seiler, W.: Biomass burning as a source of atmospheric trace gases $\mathrm{CO}, \mathrm{H}_{2}, \mathrm{~N}_{2} \mathrm{O}$, $\mathrm{NO}, \mathrm{CH}_{3} \mathrm{Cl}$ and $\mathrm{COS}$, Nature, 282, 253-256, 1979.

Crutzen, P. J. and Andreae, M. O.: Biomass burning in the tropics: Impact on atmospheric chemistry and biogeochemical cycles, Science, 150, 1669-1678, 1990.

DeCaria, A. J., Pickering, K. E., Stenchikov, G. L., Scala, J. R., Stith, J. L., Dye, J. E., Ridley, B. A., and Laroche P.: A cloudscale model study of lightning-generated $\mathrm{NO}_{\mathrm{x}}$ in an individual thunderstorm during STERAO-A, J. Geophys. Res., 105, 11 601-11 616, 2000

DeCaria, A. J., Pickering, K. E., Stenchikov, G. L. , and Ott, L. E.: Lightning-generated $\mathrm{NO}_{\mathrm{x}}$ and its impact on tropospheric ozone production: A three-dimensional modeling study of a Stratosphere-Troposphere Experiment: Radiation, Aerosols and Ozone (STERAO-A) thunderstorm, J. Geophys. Res., 110, D14303, doi:10.1029/2004JD005556, 2005.

Dentener, F., Stevenson, D., Cofala, J., et al.: The impact of air pollutant and methane emission controls on tropospheric ozone 
and radiative forcing: CTM calculations for the period 19902030 Atmos. Chem. Phys., 5, 1731-1755, 2005,

http://www.atmos-chem-phys.net/5/1731/2005/.

Desqueyroux, H., Pujet, J. C., Prosper, M., Squinazi, F., and Momas, I.: Short-term effects of low-level air pollution on respiratory health of adults suffering from moderate to severe asthma, Environ. Res., 89, 29-37, 2002

Doherty, R. M., Stevenson, D. S., Collins, W. J., and Sanderson, M. G.: Influence of convective transport on tropospheric ozone and its precursors in a chemistry-climate model, Atmos. Chem. Phys., 5, 3205-3318, 2005,

http://www.atmos-chem-phys.net/5/3205/2005/.

Ehhalt, D., Prather, M., Dentener F., et al.: Atmospheric chemistry and greenhouse gases, in Climate Change 2001: The Scientific Basis, Contribution of Working Group I to the Third Assessment Report of the Intergovernmental Panel on Climate Change, Cambridge University Press, New York, 239-288, 2001.

Fehsenfeld, F., Calvert, J., Fall, R., Goldan, P., Guenther, A. B., Hewitt, C. N, Lamb, B., Liu, S., Trainer, M., Westberg, H., and Zimmerman, P.: Emissions of volatile organic compounds from vegetation and the implications for atmospheric chemistry, Global Biogeochem. Cycles, 6(4), 389-430, 1992.

Ganzeveld, L.: Surface-Atmosphere Trace Gas and Aerosol Exchanges on the Global Scale, PhD thesis, University of Utrecht, The Netherlands, 2001.

Gates, W. L., Boyle, J. S., Covey, C., Dease, C. G., Doutriaux, C. M., et al.: An Overview of the Results of the Atmospheric Model Intercomparison Project (AMIP I), Bull. Amer. Meteorol. Soc., 80(1), pp. 2955, 1999.

Granier, C., Müller, J.-F., Madronich, S., and Brasseur, G. P.: Possible causes of the $1990-1993$ decrease in the global tropospheric CO abundance: A three dimensional sensitivity study, Atmos. Environ., 30, 1673-1682, 1996.

Granier, C., Müller, J.-F., Pétron, G., and Brasseur, G.: A threedimensional study of the global CO budget, Chemosphere Global Change Sci., 1, 255-261, 1999.

Grewe, V., Brunner, D., Dameris, M., Grenfell, J. L., Hein, R., Shindell, D., and Staehelin, J.: Origin and variability of upper tropospheric nitrogen oxides and ozone at northern mid-latitudes, Atmos. Environ. 35, 3421-3433, 2001.

Guenther, A., Hewitt, C. N., Erickson, D., Fall, R., Geron, C., Graedel, T., Harley, P., Klinger, L., Lerdau, M., Mckay, W. A., Pierce, T., Scholes, B., Steinbrecher, R., Tallamraju, R., Taylor, J., and Zimmerman, P.: A global model of natural volatile organic compound emissions, J. Geophys. Res.-Atmos., 100(D5), 8873-8892, 1995.

Guenther, A., Baugh, B., Brasseur, G., Greenberg, J., Harley, P., Klinger, L., Serca, D., and Vierling, L.: Isoprene emission estimates and uncertainties for the Central African EXPRESSO study domain, J. Geophys. Res., 104(30), 625-639, 1999.

Guenther, A., Karl, T., Harley, P., Wiedinmyer, C., Palmer, P. I, and Geron, C.: Estimates of global terrestrial isoprene emissions using MEGAN (Model of Emissions of Gases and Aerosols from Nature), Atmos. Chem. Phys., 6, 3181-3210, 2006, http://www.atmos-chem-phys.net/6/3181/2006/.

Hansen, J., Sato, M., Nazarenko, L., Ruedy, R., et al.: Climate forcings in GISS SI2000 simulations, J. Geophys. Res. 107, 4347, doi:10.1029/2001JD001143, 2002.

Helas, G., Lacaux, J. P., Delmas, R., Scharffe, D., Lobert, J.,
Goldammer, J., and Andreae, M. O.: Ozone as biomass burning product over Africa, Fresenius Environ. Bull. 1, 155-160, 1992.

Helas, G., Lobert, J., Scharffe, D., Schäfer, L., Goldammer, J., Baudet, J., Ahoua, B., Ajavon, A.-L., Lacaux, J.-P., Delmas, R., and Andreae, M. O.: Ozone production due to emissions from vegetation burning, J. Atmos. Chem. 22, 163-174, 1995

Hoke, J. E. and Anthes, R. A.: The initialization of numerical models by a dynamic-initialization technique, Mon. Wea. Rev., 104(12), 1551-1556, 1976.

Holloway, T., Levy II, H., and Kasibhatla, P.: Global distribution of carbon monoxide, J. Geophys. Res., 105, 12 123-12 147, 2000.

Horowitz, L. W., Walters, S., Mauzerall, D. L., Emmons, L. K., Rasch, P. J., Granier, C., Tie, X., Lamarque, J.-F., Schultz, M. G., Tyndall, G. S., Orlando, J. J., and Brasseur, G. P.: A global simulation of tropospheric ozone and related tracers: Description and evaluation of MOZART, version 2, J. Geophys. Res., 108(D24), 4784, doi:10.1029/2002JD002853, 2003.

Huntrieser, H., Feigl, C., Schlager, H., Schröder, F., Gerbig, C., van Velthoven, P., Flatøy, F., Théry, C., Petzold, A., Höller, H., and Schumann, U.: Airborne measurements of $\mathrm{NO}_{\mathrm{x}}$, tracer species, and small particles during the European Lightning Nitrogen Oxides Experiment, J. Geophys. Res., 107(D11), 4113, doi:10.1029/2000JD000209, 2002.

Janicot, S., Trzaska, S., and Poccard, I.: Summer Sahel-ENSO teleconnection and decadal time scale SST variations, Clim. Dyn., 18, 303-320, 2001.

Jeuken, A. B. M., Siegmund, P. C., Heijboer, L. C., Feichter, J., and Bengtson, L.: On the potential of assimilating meteorological analysis in a climate model for the purpose of model validation, J. Geophys. Res., 101, 16 939-16950, 1996.

Kesselmeier, J. and Staudt, M.: Biogenic volatile organic compounds (VOC): An overview on emission, physiology and ecology, J. Atmos. Chem., 33, 23-88, 1999.

Labrador, L. J., von Kuhlmann, R., and Lawrence, M. G.: The effects of lightning-produced NOx and its vertical distribution on atmospheric chemistry: sensitivity simulations with MATCHMPIC, Atmos. Chem. Phys., 5, 1815-1834, 2005

Lamarque, J.-F., Brasseur, G. P, Hess, P. G., and Mueller, J.-F.: Three dimensional study of the relative contributions of the different nitrogen sources in the troposphere, J. Geophys. Res., 101, 22 955-22 968, 1996.

Lawrence, M. G., Chameides, W. L., Kasibhatla, P, S., Levy II, H., and Moxim, W.: Lightning and atmospheric chemistry: The rate of atmospheric NO production, in: Handbook of Atmospheric Electrodynamics, edited by: Volland, H., Vol. I, CRC Press, Inc., Boca Raton, 189-202, 1995.

Lawrence, M. G., von Kuhlmann, R., and Salzmann, M.: The balance of effects of deep convective mixing on tropospheric ozone, Geophys. Res. Lett., 30, 18, 1940, doi:10.1029/2003GL017644, 2003.

Lin, S.-J. and Rood, R. B.: Multidimensional Flux-Form SemiLagrangian Scheme. Mon. Wea. Rev., 124, 2046-2070, 1996.

Liu, S. C., Trainer, M., Fehsenfeld, F. C., Parrish, D. D., Williams, E. J. , Fahey, D. W., Huebler, G., and Murphy, P. C.: Ozone production in the rural troposphere and the implications for regional and global ozone distributions, J. Geophys. Res., 92, 4191-4207, 1987.

Marenco, A., Medale, J. C., and Prieur, S.: Study of tropospheric ozone in the tropical belt (Africa, America) from STRATOZ and 
TROPOZ campaigns, Atmos. Environn., Ser. A, 24, 2823-2843, 1990.

Marenco, A., Thouret, V., Nédélec, P., Smit, H., Helten, M., Kley, D., Karcher, F., Simon, P., Law, K., Pyle, J., Poschmann, G., Von Wrede, R., Hume, C., and Cook, T.: Measurement of ozone and water vapor by Airbus in-service aircraft: The MOZAIC airborne program, An overview, J. Geophys. Res.-Atmos., 103(D19), 25 631-25 642, 1998.

Martin, R. V., Jacob, D. J., Logan, J. A., Bey, I., Yantosca, R. M., Staudt, A. C., Li, Q., Fiore, A. M., Duncan, B. N., and Liuiu, H., Ginoux, P., and Thouret, V.: Interpretation of TOMS observations of tropical tropospheric ozone with a global model and in situ observations, J. Geophys. Res., 107(D18), 4351, doi:10.1029/2001JD001480, 2002.

Marufu, L., Ludwig, J., Andreae, M. O.,Lelieveld J., and Helas G.: Spatial and temporal variation in biofuel consumption rates and patterns in Zimbabwe: Implications for atmospheric trace gas emissions, Biomass Bioenergy, 16, 311-332, 1999.

Marufu, L., Dentener, F., Lelieveld J., Andreae, M. O., and Helas G.: Photochemistry of the African troposphere: Influence of biomass-burning emissions, J. Geophys. Res., 105, 14513 14 530, 2000.

Mauzerall, D. L. and Wang, X. P.: Protecting agricultural crops from the effects of tropospheric ozone exposure: Reconciling science and standard setting in the United States, Europe, and Asia, Ann. Rev. Energy Environ., 26, 237-268, 2001.

Mesinger, F. and Arakawa, A.: Numerical methods used in atmospheric models, Global Atmospheric Research Programme (GARP) Publication Series 17, World Meteorological Organisation, 1976.

Mortimer, K. M., Neas, L. M., Dockery, D. W., Redline, S., and Tager, I. B.: The effect of air pollution on inner-city children with asthma, Eur. Respiratory J., 19, 699-705, 2002.

Naik, V., Mauzerall, D., Horowitz, L., et al.: Net radiative forcing due to changes in regional emissions of tropospheric ozone precursors J J. Geophys. Res., 110(D24), D24306, doi:10.1029/2005JD005908, 2005.

Nordeng, T. E.: Extended versions of the convective parameterization scheme at ECMWF and their impact on the mean and transient activity of the model in the tropics. Technical memorandum No. 206, European Centre for Medium-range Weather Forecasts (ECMWF), Reading, United Kingdom, 1994.

Novelli, P. C., Steele, L. P., and Tans, P. P.: Mixing ratios of carbon monoxide in the troposphere, J. Geophys. Res., 97, 20731 20750, 1992.

Novelli, P. C., Masarie, K. A., Tans, P. P., and Lang, P. M.: Recent changes in atmospheric carbon monoxide, Science, 263, 15871590, 1994.

Novelli, P. C., Anderson, B. E., Brenninkmeijer, C. A. M., Brunke, E. G., Doddridge, B. G., et al.: An internally consistent set of globally-distributed atmospheric carbon monoxide mixing ratios developed using results from an intercomparison of measurements, J. Geophys. Res., 103, 19285-19293, 1998a.

Novelli, P. C., Masarie, K. A., and Lang, P. M.: Distributions and recent changes of carbon monoxide in the lower troposphere, $\mathrm{J}$. Geophys. Res., 103, 19015-19033, 1998b.

Novelli, P. C., Masarie, K. A., Lang, P. M., Hall, B. D., Myers, R. C., and Elkins, J. W.: Reanalysis of tropospheric CO trends: Effects of the 1997-1998 wildfires, J. Geophys. Res., 108(D15),
4464, doi:10.1029/2002JD003031, 2003.

Oksanen, E., and Holopainen, T.: Responses of two birch (Betula pendula Roth) clones to different ozone profiles with similar AOT40 exposure, Atmos. Environ., 35, 5245-5254, 2001.

Olivier, J., Bouwman, A., Berdowski, J., Bloos, J., Visschedijk, A., van der Mass, C., and Zandveld, P.: Sectoral emission inventories of greenhouse gases for 1990 on a per country basis as well as on $1 \times 1$ degrees, Environ. Sci. Policy, 2, 241-263, 1999.

Palmer, T. N., Brankovic, C., Viterbo, P., and Miller, M. J.: Modeling inter-annual variations of summer monsoons, J. Clim., 5, 399 -417, 1992.

Peden, D. B.: Air pollution in asthma: effect of pollutants on airway inflammation, Annals Allergy Asthma and Immunology, 87, 1217, 2001.

Pickering, K. E., Thompson, A. M., Dickerson, R. R., Luke, W. T., McNamara, D. P., Greenberg, J., and Zimmerman, P. R.: Model calculations of tropospheric ozone production potential following observed convective events, J. Geophys. Res., 95, 14049 $14062,1990$.

Pickering, K. E., Thompson, A. M., Wang. Y., Tao, W., McNamara, D. P., Kirchhoff, V. W. J. H., Heikes, B. G., Sachse, G. W., Bradshaw, J. D., Gregory, G. L., and Blake, D. R.: Convective transport of biomass burning emissions over Brazil during TRACE-A, J. Geophys. Res., 101, 23 993-24 012, 1996.

Pickering, K. E., Wang, Y., Tao, W., Price, C., and Müller, J.: Vertical distributions of lightning NOx for use in regional and global chemical transport models, J. Geophys. Res., 103(D23), 31203 $31216,1998$.

Price, C., Penner, J., and Prather, M.: $\mathrm{NO}_{\mathrm{x}}$ from lightning: 1. Global distribution based on lightning physics, J. Geophys. Res., 102, 5929-5941, 1997.

Prinn, R.G., Weiss, R. F., Miller, B. R., Huang, J., Alyea, F. N., Cunnold, D. M., Fraser, P. J., Hartley, D. E., and Simmonds, P. G.: Atmospheric Trends and Lifetime of $\mathrm{CH}_{3} \mathrm{CCl}_{3}$ and Global OH Concentrations, Science, 269, 5221, 187-192, 1995.

Randerson, J. T., Kasibhatla, P. S., Kasischke, E. S., Hyer, E. J., Giglio, L., Collatz, G. J., and van der Werf, G. R.: Global Fire Emissions Database (GFED), Version 1. Data set, available online http://daac.ornl.gov/ from Oak Ridge National Laboratory Distributed Active Archive Center, Oak Ridge, Tennessee, USA, 2005 .

Ridley, B. A., Dye, J. E., Walega, J. G., Zheng, J., Grahek, F. E., and Rison, W.: On the production of active nitrogen by thunderstorms over New Mexico, J. Geophys. Res., 101, 20 985-21 005, 1996.

Reichle Jr., H., Anderson, B. E., Connors, V. S., Denkins, T. C., Forbes, D. A., et al.: Space shuttle based global CO measurements during April and October 1994, MAPS instrument, data reduction, and data validation, J. Geophys. Res., 104, 21443 $21454,1999$.

Robert, A. J., Henderson, J., and Turnbull, C.: An implicit time integration scheme for baroclinic models in the atmosphere, Mon Wea. Rev., 100, 329-335, 1972.

Robert, A. J.: A stable numerical integration scheme for the primitive meteorological equations, Atmos. Ocean, 19, 35-46, 1981.

Robert, A. J.: A semi-Lagrangian and semi-implicit numerical integration fscheme for the primitive meteorological equations, J. Met. Soc. Japan, 60, 319-325, 1982.

Roeckner, E., Bäuml, G., Bonaventura, L., Brokopf, R., Esch, M., 
Giorgetta, M., Hagemann, S., Kirchner, I., Kornblueh, L., Manzini, E., Rhodin, A., Schlese, U., Schulzweida, U., and Tompkins, A.: The atmospheric general circulation model ECHAM5, part I: Model description, Max Planck Institute for Meteorology, Report No. 349, 2003.

Roeckner, E., Brokopf, R., Esch, M., Giorgetta, M., Hagemann, S., Kornblueh, L., Manzini, E., Schlese, U., and Schulzweida, U.: Sensitivity of simulated climate to horizontal and vertical resolution in the ECHAM5 atmosphere model, J. Clim., 19, 16, 37713791, doi: 10.1175/JCLI3824.11, 2006.

Sauvage B., Thouret, V., Cammas, J- P., Gheusi, F., G. Athier, G. and Nédéléc, P.: Tropospheric ozone over Equatorial Africa: regional aspects from the MOZAIC data, Atmos. Chem. Phys., 5, 311-335, 2005, http://www.atmos-chem-phys.net/5/311/2005/.

Schultz, M. G. and Bey, I.: Numerical modeling of long-range pollution transport, Chp. 8, in: Intercontinental Transport of Air Pollution, edited by: Stohl, A., Springer, New York, 2004.

Seinfeld, J. H. and Pandis, S. N.: Atmospheric Chemistry and Physics: From Air pollution to Climate change, John Wiley, United States of America, 1998.

Shindell, D. T., Faluvegi, G., Stevenson, D. S., et al.: Multimodel simulations of carbon monoxide: Comparison with observations and projected near-future changes J. Geophys. Res., 111(D19), D19306, doi:10.1029/2006JD007100, 2006.

Simmons, A. J and Burridge, D. M.: An energy and angularmomentum conserving vertical finite difference scheme and hybrid vertical coordinates, Mon. Wea. Rev., 109, 758-766, 1981.

Stevenson, D. S., Dentener, F. J., Schultz, M. G., Ellingsen, K., van Noije, T. P. C., et al.: Multi-model ensemble simulations of present-day and near-future tropospheric ozone, J. Geophys. Res., 111(D8), D08301, doi:10.1029/2005JD006338, 2006.

Stier, P., Feichter, J., Kinne, S., Kloster, S., Vignati, E., Wilson, J., Ganzeveld, L., Tegen, I., Werner, M., Balkanski, Y., Schulz, M., Boucher, O., Minikin, A., and Petzold, A.: The aerosolclimate model ECHAM5-HAM, Atmos. Chem. Phys., 5, 11251156, 2005, http://www.atmos-chem-phys.net/5/1125/2005/.

Thompson, A. M., Doddridge, B. G., Witte, J. C., Hudson, R. D., Luke, W. T., et al.: A Tropical Atlantic Paradox: Shipboard and Satellite Views of a Tropospheric Ozone Maximum and Waveone in January-February 1999, Geophys. Res. Lett., 27, 33173320, 2000.

Thompson, A. M., Witte, J. C., McPeters, R. D., Oltmans, S. J., Schmidlin, F. J., Logan, J. A., et al.: Southern Hemisphere Additional Ozonesondes (SHADOZ) 1998-2000 tropical ozone climatology 1: Comparison with Total Ozone Mapping Spectrometer (TOMS) and ground-based measurements, J. Geophys. Res., 108(D2), 8238, doi:10.1029/2001JD000967, 2003.
Thompson, A. M., Witte, J. C., Oltmans, S. J., Schmidlin, F. J., Logan, J. A., et al.: Southern Hemisphere Additional Ozonesondes (SHADOZ) 1998-2000 tropical ozone climatology 2: Tropospheric variability and the zonal wave-one, J. Geophys. Res., 108(D2), 8241, doi:10.1029/2002JD002241, 2003.

Thouret, V., Marenco, A., Logan, J. A., Nédélec, P., and Grouhel, C.: Comparison of ozone measurements from the MOZAIC airborne program and the ozone sounding network at eight locations, J. Geophys. Res., 103(D19), 25 695-25 720, 1998a.

Thouret, V., Marenco, A., Nédélec, P., and Grouhel, C.: Ozone climatologies at 9-12 km altitude as seen by the MOZAIC airborne program between September 1994 and August 1996, J. Geophys. Res., 103(D19), 25 653-25 680, doi:10.1029/98JD01807, 1998b.

Thouret, V. , Cammas, J.-P., Sauvage, B., Athier, G., Zbinden, R., Nédélec, P., Simon, P., and Karcher, F.: Tropopause referenced ozone climatology and inter-annual variability (1994-2003) from the MOZAIC programme, Atmos. Chem. Phys., 6, 1033-1051, 2006,

http://www.atmos-chem-phys.net/6/1033/2006/.

Tie, X., Zhang, R. , Brasseur, G., Emmons, L., and Lei, W.: Effects of lightning on reactive nitrogen and nitrogen reservoir species in the atmosphere, J. Geophys. Res., 106, 3167-3178, 2001.

Tie, X., Guenther, A., and Holland, E.: Biogenic methanol and its impact on tropospheric oxidants, Geophys. Res. Lett., 30(17), 1881, doi:10.1029/2003GL017167, 2003.

Tiedtke, M.: A comprehensive mass flux scheme for cumulus parameterization in large-scale models, Mon. Wea. Rev., 117, 1779-1800, 1989.

von Kuhlmann, R., Lawrence, M. G., Pöschl, U., and Crutzen, P. J.: Sensitivities in global scale 25 modeling of isoprene, Atmos. Chem. Phys., 4, 1-17, 2004, http://www.atmos-chem-phys.net/4/1/2004/.

Wang, W. C., Pinto, J. P., and Yung, Y. L.: Climatic effect due to halogenated compounds in the Earth's atmosphere, J. Atmos. Sci., 37, 333-338, 1980.

Wang, K.-Y. and Shallcross, D. E: Modelling terrestrial biogenic isoprene fluxes and their potential impact on global chemical species using a coupled LSM-CTM model, Atmos. Environ., 34, 2909-2925, 2000.

Zbinden, R. M., Cammas, J.-P., Thouret, V., Nédélec, P., Karcher, F., and Simon, P.: Mid-latitude tropospheric ozone columns from the MOZAIC program: climatology and interannual variability Atmos. Chem. Phys., 6, 1053-1073, 2006, http://www.atmos-chem-phys.net/6/1053/2006/. 